14

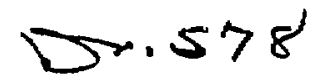

$\left.v\right|^{0}$

UCRL-51484

\title{
PROJECT RIO BLANCO SPALL MEASUREMENTS DATA REPORT
}

Clyde Slsemore

John Tomen

November 14, 1973

Prepared for U.S. Atomic Energy Commission under contract No. W-7405-Eng-48

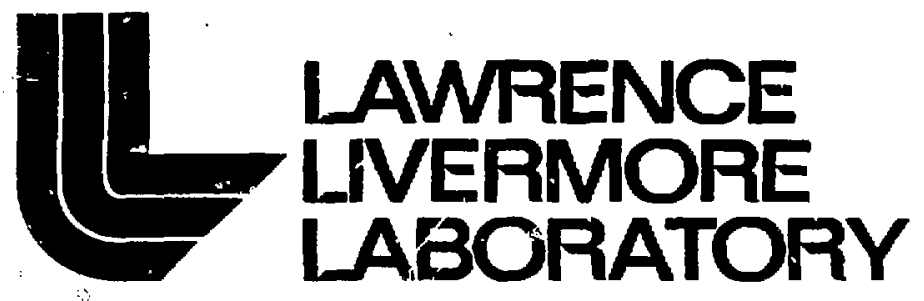

University of California/Livermore 
Notrot

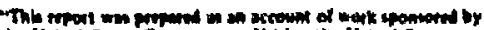

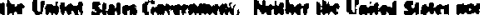

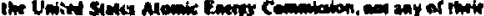

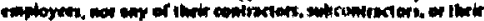

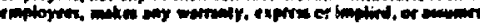

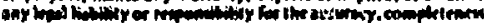

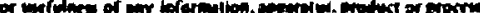

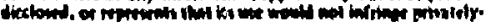
comed rithe.

Printed in the United States of America Available from

Nationel Technlcal Information Service

U. S. Department of Commerce 5285 Port Royal Road

Springfield, Virginia 22151

Price: Printed Copy \$ *; Microfiche $\mathbf{\$ 0 . 9 5}$

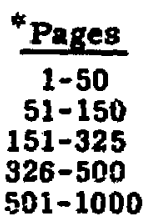

NTIS

Selling Price

$\$ 4.00$

$\$ 5.45$

$\$ 7.60$

$\$ 10.60$

$\$ 13.60$ 
TLD-4500, $\mathrm{CC}-30$

Peaceful Applications of Explosions

\section{노 \\ LAWRENKE LMERMORE LABORATORY

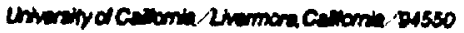

\section{UCR L-51484 \\ PROJECT RIO BLANCO SPALL MEASUREMENTS \\ DATA VEPORT \\ Clyde Sisemore \\ John Toman}

MS. date: November 14, 1973

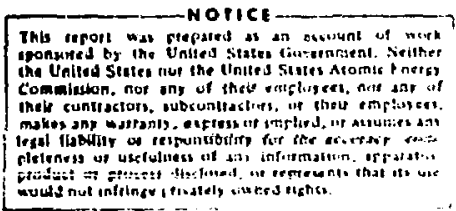




\section{Contents}

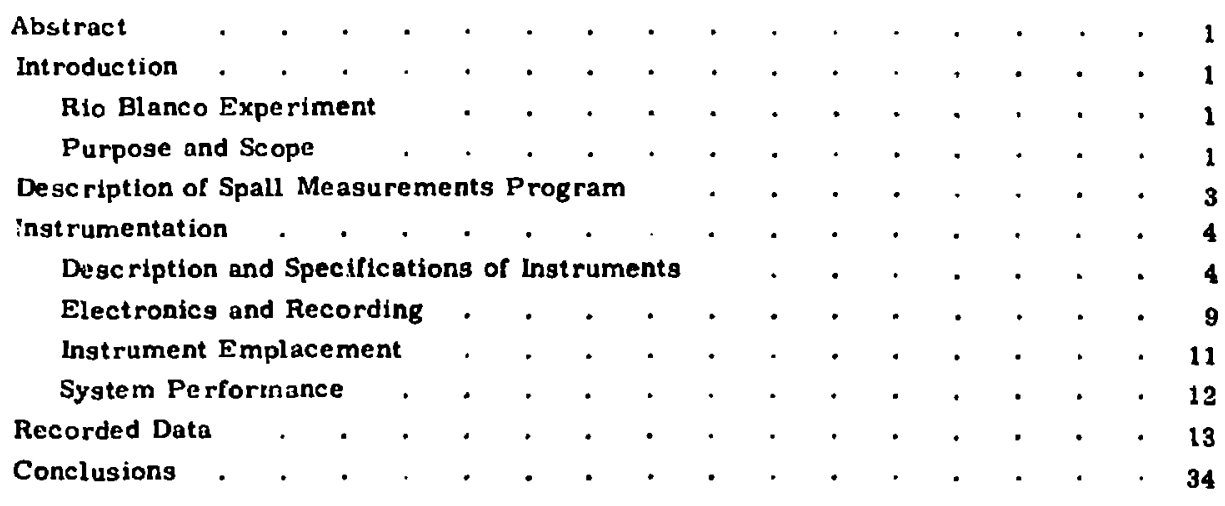




\title{
PROJECT RIO BLANCO SPALL MEASUREMENTS DATA REPORT
}

\begin{abstract}
A major instrumentation program was undertaken for the Rio Blanco experiment using accelerometers and velocity gages burled at various depths below the ground surface and at various horizontal ranges from the emplacement well. The objective

was to physically measure the depth and aerial extent of spall (tensile failure of the earth material). Data from each of the instrument stations is given, along with the appropriate integrated data for particle velocity and displacement or iust displacerient.
\end{abstract}

\section{Introduction}

\section{RIO BLANCO EXPERIMENT}

\section{Project Rio Blanco was a joint}

Government-Industry experiment to stimulate a natural gas reservoir using three 30-kiloton nuclear explosives in a single well bore (emplacement depths were 5840,6230 , and $6690 \mathrm{ft}$ ). The three explosives were detonated nearly siniultaneously at 1000:00.12 $\pm 0.01 \mathrm{sec}$ MDT, May 17, 1973. The emplacement well (EW), at an elevation of $6629.9 \mathrm{ft}$ above mean sea level, is located $1080.5 \mathrm{ft}$ south of the north line and $1188.5 \mathrm{ft}$ east of the wert line in Section 14, Township 3 South, Range 98 West of 6th Prime Meridian (P. M.), Rio Blanco County, Colorado. The geodetic coordinates ure $108^{\circ} 21^{\prime} 59^{\prime \prime}$ west longitude and $39^{\circ} 47^{\prime} 35^{\prime \prime}$ north latitude. The site as shown in Fig, 1 is 52 miles north of Grand Junction, 31 miles south- east of Rangely, 30 miles southwest of Meeker, and 37 milee northwest of Rifle, all in Colorado.

\section{PURPOSE AND SCOPE}

This report presents data obtained from the spall measurements program which was undertaken as part of Project Rio Blanco to determine the depth below the ground surface of failures (spall) in the rock caused by excessive tensile stress. Spall occurs whenever, at some subsurface point, the ascending compression wave and the surface reflected tension wave interact to give a tensile stress larger than the fallure strength of the rock at that point.

The spall measurement program was designed and fielded to verify theoretical calculations which led to the conclusion 


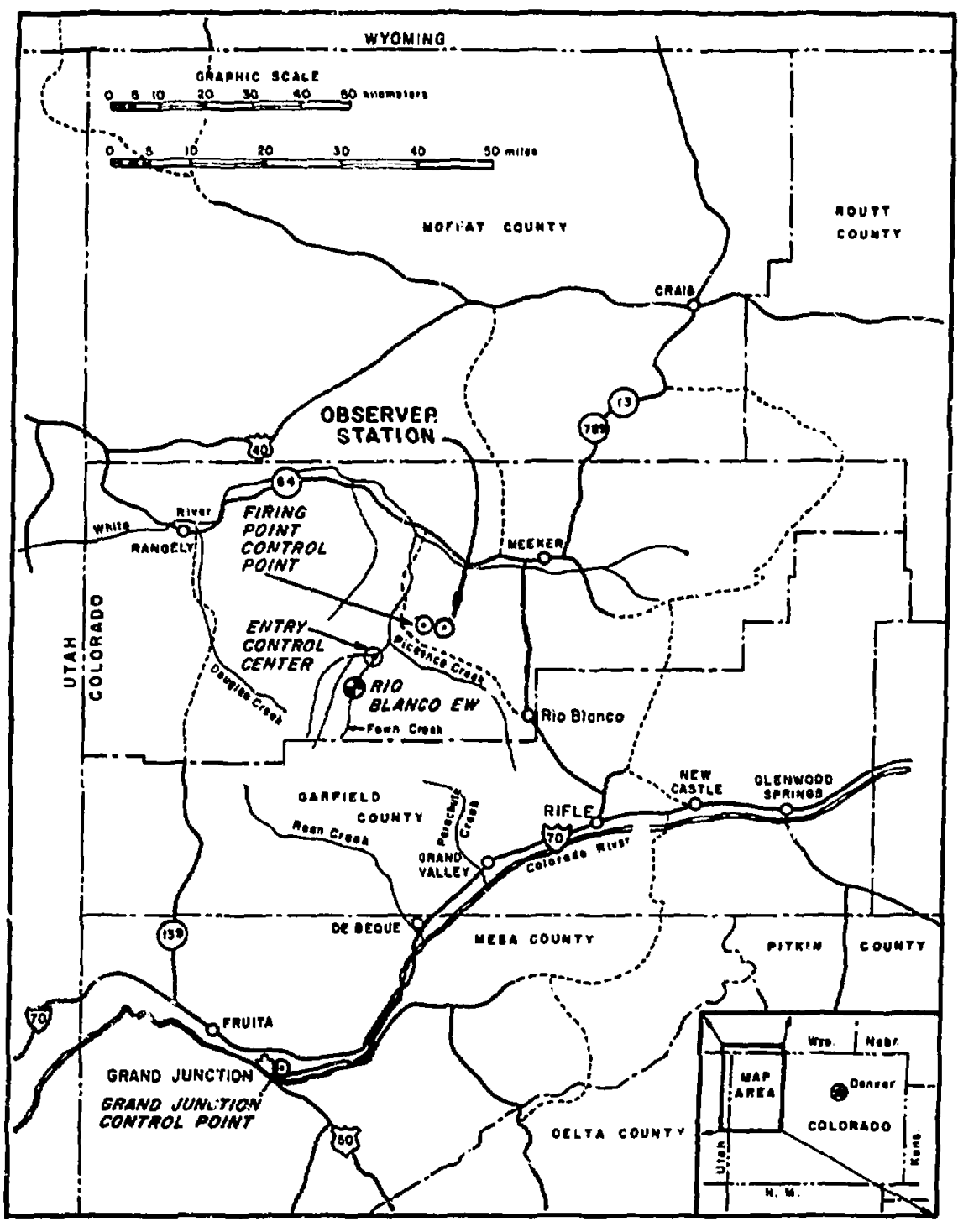

Fig. 1. Rio Blanco site location. 
that spalling would not extend down into a rich oil shale zone located al a depth of about 750 to $900 \mathrm{ft}$ below the ground surface. An oil shale company projectcd that any new sractures would increase the room and plllar mining costs enorgh to make oil shale development uneconomic. The primary purpose of these mensurements then was to experimentally locate the dcepest spall zone. Since theorctieal calculations had been made to predici spall depths, a secondary goal was to establish the validity of these predetonethon calculated values. A list of the prefetonation predictions, a description of the experimental miethods to be employod in the fteld, anci a summary of past exper:ence with this method have been reported.

\section{Description of Spall Measurements Program}

In brief, the method employed to detect the occurrence of spall utilized accelerometers and velocity gages at vartous depths below the ground surface to record earth motion histories at several subsurface locations. Material which has been spalled (placed in free flight) exhibits characteristic acceleration and velocity histories which can be used to define spall zones. This is accompllshed by assigning all the material above an ingtrumrant displaying spall chareater!stics to a spalled region and all the mate rial below an inSi ument displaying only free field characteristics to a regioin free of apall. Since the maximum depth of spall would be at some unknown depth between two instruments, the precision with which this method can establish the maximum depth of spall depends on the number of instruments used and their spacing. This uncertainty for Project Rio Blanro wa's a maximum of $150 \mathrm{ft}$.

A total of 36 gages (20 accelerometers and 16 velocity gages) were used at 20 different locations. Most of these instruments were installed in six instrument holes located withan $7300 \mathrm{ft}$ of the $\mathrm{EW}$, an at emplacement depths ranging from is $t_{4}$ 821 ft (Fig. 2). Two additional su.face accelerometers were placed at distances of 12,000 and 23,000 ft fro: the EW.

In addition to the above instrumeni, cliper cables were installed in five, it the six instrument holes to provide nn idependent chesis on the spall depth (1 ig. 2 ). This cltper transducer system, using time domain reflectrometry, can continuously measure the length of a cable during a specified length of time. Therciore, any cable break caused by spall during this specified time can be identified accurately with respect to time and location (depth).

1. J. Toman. R. Terhune and C. Sisemore, Spull Measurements Program For Rio Blanco, Lawrence Livermore Laboratory, Rept. UCID-1607 8 (1572), 


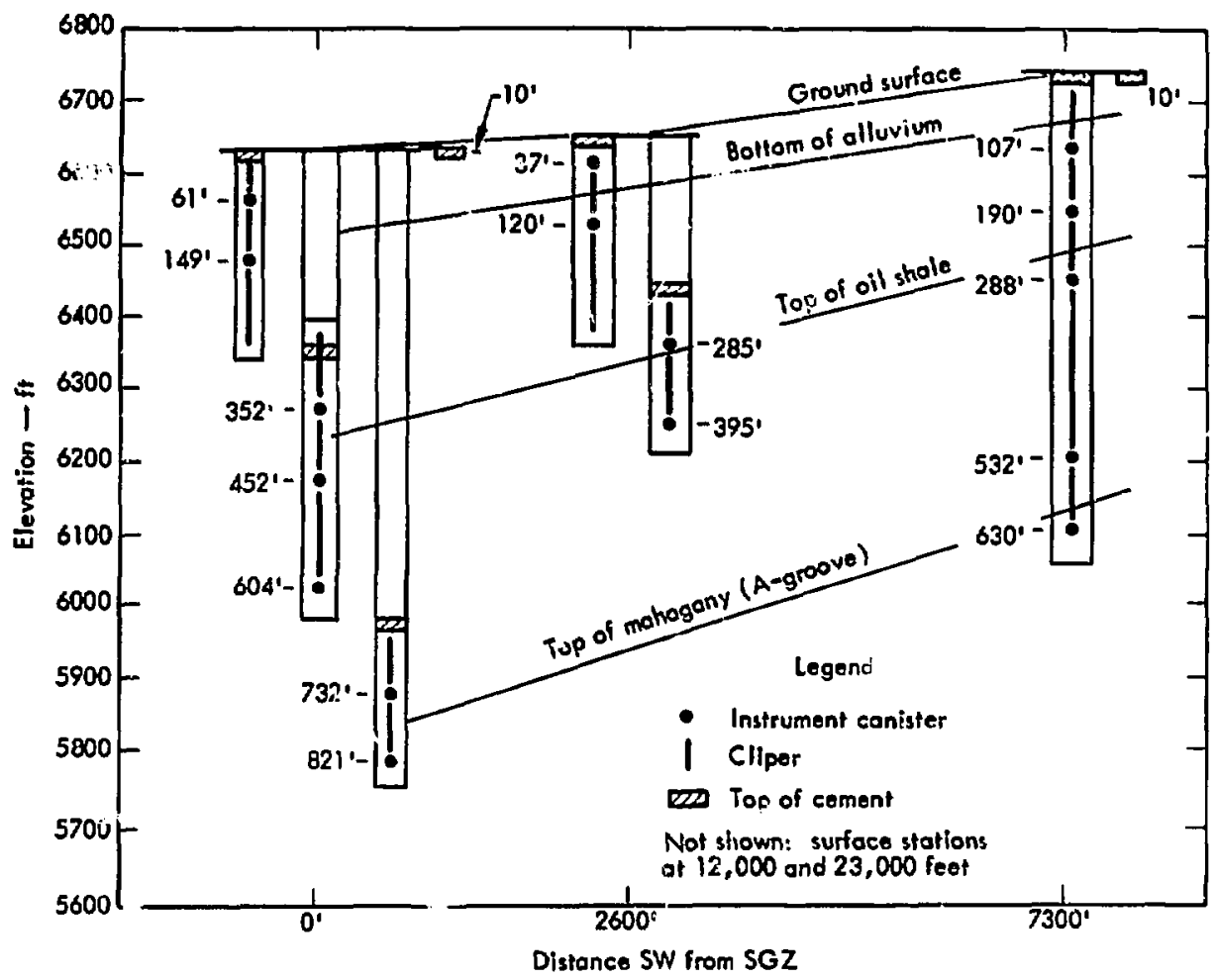

Fig. 2. Instrument hole locations.

\section{Instrumentation}

DESCRIPTION AND SPECIFICATIONS OF INSTRUMENTS

A total of 16 canisters, each ccitaining an accelerometer and velocity gage, were installed at locations which are shown in Fig. 2 and Table 1. The canister as shown in Fig. 3 also contai..ed a thermistor, two explosive cable cutting devices and two release monitoring systems. The thermistcr was used to measure the shot time temperature at each canister. These data were used later to correct the velocity gage outputs for the variations generated by temperature-induced changes in the oil viscosity. The cable cutting devices were used to sever the emplacement wire rope at each end of the canister. Their purpose was to free the canister from any part of the emplacement paraphernalia so motion of the unit would be similar to that of the surrounding rock. The release monitoring 
Table 1. Summary of instrumentation.

\begin{tabular}{|c|c|c|c|c|c|c|}
\hline $\begin{array}{c}\text { Gage } \\
\text { designation }\end{array}$ & $\begin{array}{c}\text { Hole } \\
\text { designation }\end{array}$ & $\begin{array}{l}\text { Horizontal } \\
\text { range } \\
\text { (ft) }\end{array}$ & $\begin{array}{c}\text { Depth } \\
\text { (ft) }\end{array}$ & $\begin{array}{l}\text { Slant } \\
\text { range }^{a} \\
\text { (ft) }\end{array}$ & $\begin{array}{l}\text { Depth } \\
\text { top of } \\
\text { cement } \\
\text { (ft) }\end{array}$ & $\begin{array}{c}\text { Release } \\
\text { operation } \\
\text { upper: } \\
\text { lower }\end{array}$ \\
\hline $\begin{array}{l}00 A C 00 \\
01 \mathrm{AC} 80 \mathrm{~V} \\
01 \mathrm{AC} 150 \mathrm{~V}\end{array}$ & $\begin{array}{l}\text { Surface } \\
\text { RBS-01 } \\
\text { RBS-01 }\end{array}$ & $\begin{array}{l}138.23 \\
148.26 \\
148.26\end{array}$ & $\begin{array}{r}25 \\
61 \\
149\end{array}$ & $\begin{array}{l}6216 \\
6170 \\
6082\end{array}$ & $\begin{array}{c}\text { Surface } \\
10 \\
10\end{array}$ & $\begin{array}{l}\text { NA } \\
\text { Yes-No } \\
\text { No-Yes }\end{array}$ \\
\hline $\begin{array}{l}02 \mathrm{AC} 350 \mathrm{~V} \\
02 \mathrm{AC} 450 \mathrm{~V} \\
02 \mathrm{AC} 600 \mathrm{~V}\end{array}$ & $\begin{array}{l}\text { RBS-02 } \\
\text { RBS-02 } \\
\text { RBS-02 }\end{array}$ & $\begin{array}{l}128.43 \\
128.43 \\
128.43\end{array}$ & $\begin{array}{l}352 \\
452 \\
604\end{array}$ & $\begin{array}{l}5879 \\
5779 \\
5627\end{array}$ & $\begin{array}{l}272 \\
272 \\
272\end{array}$ & $\begin{array}{l}\text { No-Yes } \\
\text { No-Yes } \\
\text { Yes-Yes }\end{array}$ \\
\hline $\begin{array}{l}03 \mathrm{AC} 720 \mathrm{~V} \\
03 \mathrm{AC} 820 \mathrm{~V}\end{array}$ & $\begin{array}{l}\text { RBS-03 } \\
\text { RBS-03 }\end{array}$ & $\begin{array}{l}130.48 \\
130.48\end{array}$ & $\begin{array}{l}723 \\
821\end{array}$ & $\begin{array}{l}\mathbf{5 5 0 8} \\
\mathbf{5 4 1 0}\end{array}$ & $\begin{array}{l}633 \\
633\end{array}$ & $\begin{array}{l}\text { No-Yes } \\
\text { Yes-Yes }\end{array}$ \\
\hline $\begin{array}{l}04 \mathrm{AC} 30 \mathrm{~V} \\
04 \mathrm{AC} 120 \mathrm{~V}\end{array}$ & $\begin{array}{l}\text { Surface } \\
\text { RBS-04 }\end{array}$ & $\begin{array}{l}2420 \\
2435\end{array}$ & $\begin{array}{r}35 \\
120\end{array}$ & $\begin{array}{l}6683 \\
6610\end{array}$ & $\begin{array}{c}\text { Surface } \\
5\end{array}$ & $\begin{array}{l}\text { NA } \\
\text { No-Yes }\end{array}$ \\
\hline $\begin{array}{l}\text { 05AC280V } \\
05 \mathrm{AC} 380 \mathrm{~V} \\
7300 \mathrm{ACOOV} \\
06 \mathrm{AC} 90 \mathrm{~V} \\
06 \mathrm{AC} 190 \mathrm{~V} \\
06 \mathrm{AC} 290 \mathrm{~V} \\
06 \mathrm{AC} 550 \mathrm{~V} \\
\text { 06AC630V }\end{array}$ & $\begin{array}{l}\text { RBS-05 } \\
\text { RBS-05 } \\
\text { Surface } \\
\text { RBS-06 } \\
\text { RBS-06 } \\
\text { RBS-06 } \\
\text { RBS-06 } \\
\text { RBS-06 }\end{array}$ & $\begin{array}{l}2413 \\
2413 \\
7200 \\
7248 \\
7248 \\
7248 \\
7248 \\
7248\end{array}$ & $\begin{array}{r}285 \\
398 \\
15 \\
107 \\
190 \\
288 \\
532 \\
630\end{array}$ & $\begin{array}{l}6449 \\
6344 \\
9516 \\
9560 \\
9506 \\
9443 \\
9288 \\
9227\end{array}$ & $\begin{array}{c}200 \\
200 \\
\text { Surface } \\
3 \\
3 \\
3 \\
3 \\
3\end{array}$ & $\begin{array}{l}\text { Yes-Yes } \\
\text { No-Yes } \\
\text { NA } \\
\text { No-Yes } \\
\text { No-Yes } \\
\text { No-Yes } \\
\text { No-Yes } \\
\text { Yes-Yes }\end{array}$ \\
\hline $\begin{array}{l}12000 \mathrm{ACOOV} \\
23000 \mathrm{ACOOV}\end{array}$ & $\begin{array}{l}\text { Surface } \\
\text { Surface }\end{array}$ & $\begin{array}{l}12034 \\
\sim 23000\end{array}$ & $\begin{array}{l}15 \\
15\end{array}$ & $\begin{array}{l}13450 \\
-23828\end{array}$ & $\begin{array}{l}\text { Surface } \\
\text { Surface }\end{array}$ & $\begin{array}{l}\text { NA } \\
\text { NA }\end{array}$ \\
\hline
\end{tabular}

${ }^{a}$ The slant range is measured from the center explosive at a depth of $6230 \mathrm{ft}$.

system determined whether both cutting devices functioned properly.

Spall can be readily identified in records of surface motion, and therefore only acceleration was measured at the surface stations. However, subsurface detection of spall was expected to be more difficult, and both velocity and acceleration were measured at each subsurface station. In addition, at each of these stations, only single vertical component transducers were used for each parameter. This restriction in data was possible because in the stated experimental method only the vertical component of motion is needed to determine free fall and thus the "spall" or "no-spall" condition of the surrounding material.

All accelerometers were "force balance" servo units (Kistler model 305A)." As shown in Fig. 4, the working components of these units are a mass, a permanent magnet, a forcer coil, a displacement sensor, and an amplifier. In operation, the displacement unit senses movement of the seismic mass relative to the case. The amplifier feedback sysiem then converts

\footnotetext{
Reference to a company or product name does not imply approval or recommendation of the product by the University of California or the U.S. Atomic Energy Commission to the exclusion of others that may be suitable.
} 


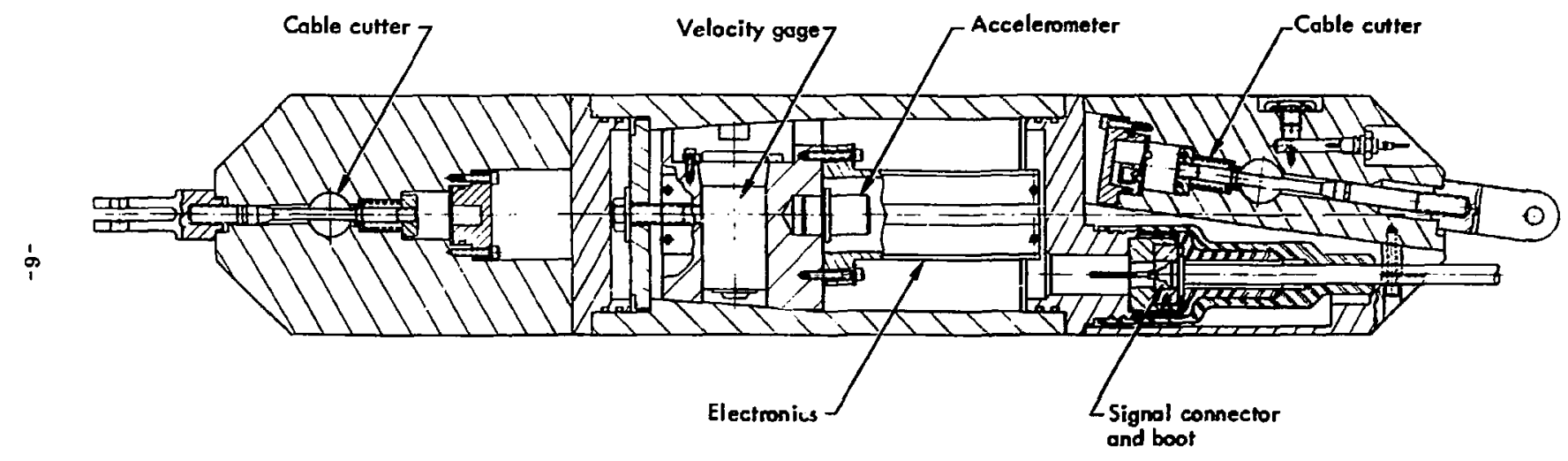

Fig. 3. Canister drawing. 


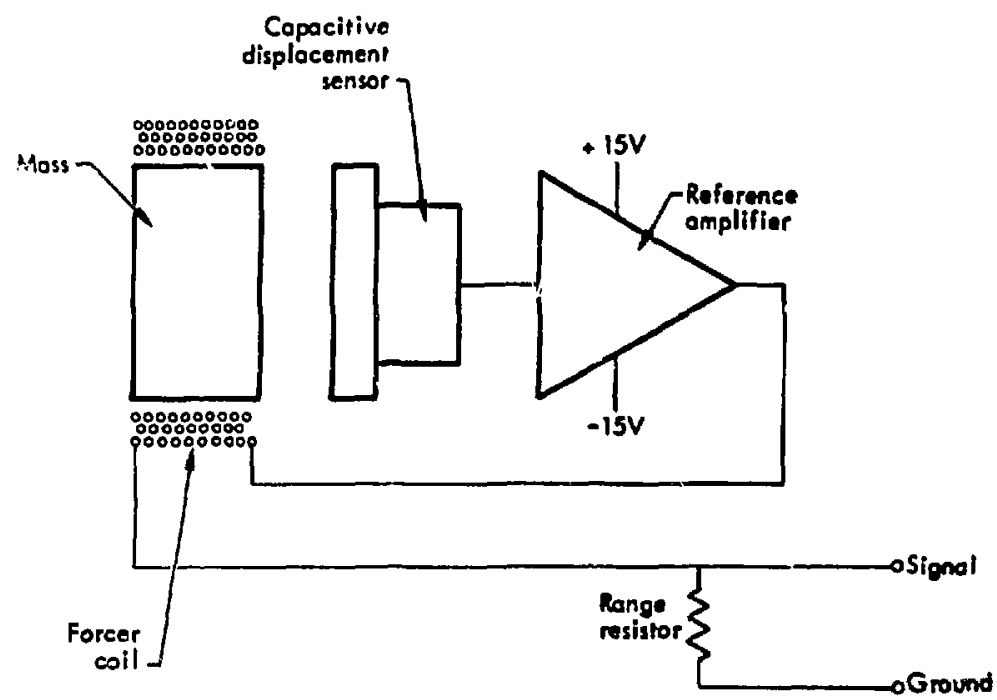

Fig. 4. Servo accelerometer schematic (Kistler Model 305A).

this displacement signal into the specific amount of electrical current needed by the forcer coil to bring the separation between the seismic mass and the displacement sensor back to its original value. In this manner, the spatial separation between the seismic mass and the displacement sensor is held constant by the mechanism of balancing the input force created by an acceleration imparted to the case against an equal and opposite electronically generated restoring force. Since the restoring force is proportional to the acceleration of the transducer case, the current needed to generate this force must be proportional to the acceieration. The transducer design is complete if this current can be sampled and recorded. The accelerometer's specifications are as follows:
Range
0 to $\pm 50 \mathrm{~g}$
Sensitivity
$0.200 \mathrm{~mA} / \mathrm{g}$

\begin{tabular}{ll} 
Frequency Response & $\mathrm{DC}-500 \mathrm{~Hz}$ \\
Natural Frequency & $1000 \mathrm{~Hz}$ \\
Damping & 0.6 \\
Welght & $3.4 \mathrm{oz}$ \\
Case diameter & $1.125 \mathrm{in}$. \\
$\begin{array}{c}\text { Suspension of } \\
\text { seismic element }\end{array}$ & $\begin{array}{c}\text { Translational } \\
\text { nexure }\end{array}$ \\
\hline
\end{tabular}

The particle velocity transducer (Spartan model 603V) used for these measurements was a highly damped massspring mechanical system. The gage as shown in Fig. 5 was developed at Stanford Research Institute, with later improvements by the Albuquerque Sundia Laborztory. 2,3 The gage proved to be useful in many areas,

2. 2. M. Swin, Development of an Earth Velocity Gagc, DASF-T101 Toct. 31. TIJ6).

3. W. P. Perret, J. W. Wistor, G. J. Hansen and D. G. Palmer, Four Papers Concerning Recent Work on Ground Morion heasurements, Sandia Laborazorics, Albuquerque, Rept. Sc-R-6S-904 (1965). 

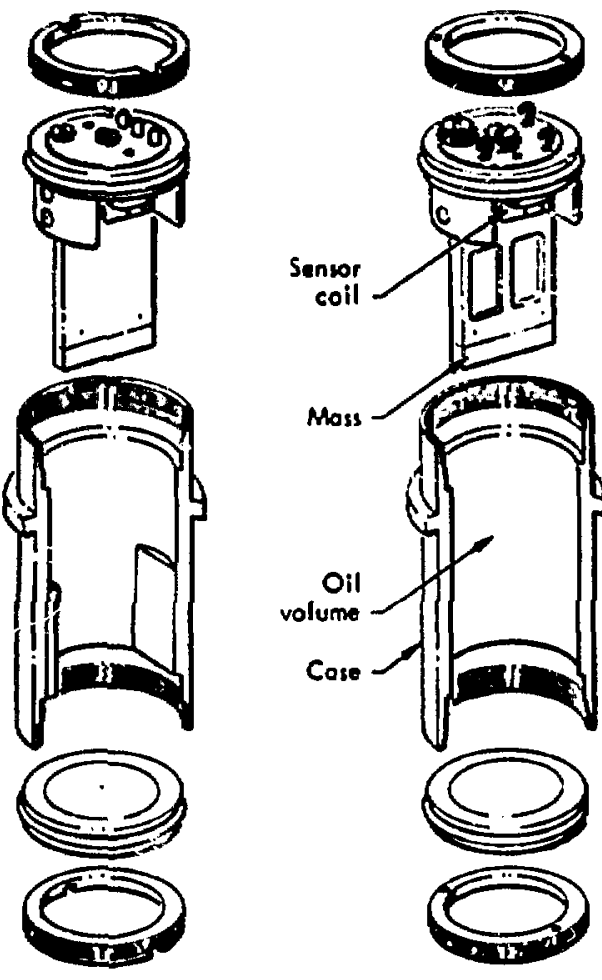

Fig. 5. Particle velocity gage (Spartan wodel 603 V).

and it has been used extensively over the past ten years by several laboratories. including LLL.

This system is made up of a pendulum (mass) and a volume of viscous liquid sillicone oil. The pendulum (actually a paddle) is placed in the liquid such that its motion is constrained only by its pivots and the viscosity of the liquid. If the frequency content of the input signal is limited to a frequency span centered around the resonance frequency of the paddle system, the angle of the paddle in the viscous fluid is proportional to the magnitude of the velocity imparted to the iransducer case. Given these operatienal conditions, this system will measure the particle velocity of the surrounding rock if the unt is well coupled to the rack. Sensing and recording the angular position of the paddlo provides a velocity history at the location of the instrument.

A variable reluctance sysinn senses the angular position of the pacldle. Two colls are rigidly mounted to the case so that the ends of the coils are in close proximity to two blades attached to the free moving paddle. As the paddle moves, the spatial separation between coll and blade changes, and since the inductances of the two colls are directly dependent on the separation between colls and blades, any change in paddle position is reflected by a cliange in inductances of the two coils. Now, if these two inductances are used to control the frequencics of two local oscillators, the paddle pus::ion can be determined from the relationship between the frequencies of the two oscillators.

The outputs of the two oscillators are then mixed to reduce the number of signal channels and to reduce the dependence of the paddle position measurement to just one frequency. Obviously, this transducer system would function properly with just one oscillator coll arrangement, but using two improves lincarity and doubles the sensitivity. Since sensitivity and linearity are important parameters in this measurement, two oscillator-coil ai-rangements were used. Using the appropriate calibrations, this output frequency can be made directly proportional to the velocity experienced by the transulucer case. 
Speciflcations of the velocity gage are as follows:

\begin{tabular}{|c|c|}
\hline Range & $\begin{array}{r} \pm 10 \mathrm{rt} / \mathrm{sec} \text { to } \\
\pm 500 \mathrm{ft} / \mathrm{sec}\end{array}$ \\
\hline Sensitivity & $4 \mathrm{ft} / \mathrm{sec} / \mathrm{kHz}$ \\
\hline $\begin{array}{l}\text { Frequency } \\
\text { response }\end{array}$ & $150 \mathrm{~Hz}$ \\
\hline Natural frequency & 3 Hz \\
\hline Damping & 50 \\
\hline Welght & $507 \mathrm{~g}$ \\
\hline Case dlameter & $1.62 \mathrm{ic}$ \\
\hline Case length & 3.14 in. \\
\hline
\end{tabular}

Suspension of seismic element

\section{EL.BCTRONICS AND RECORDING}

The electronics recording scheme was designed to provide two levels of accelera- tion data and one level of velocity data. The two levela of acceleration were obtained by taking the accelerometer output and applying it to the inputs of two voltage control oscillators (VCO); each operating with a different goin. The VCO center carriers were arranged to have a $300-\mathrm{kHz}$ unit with a low gain and a 1200-kHz unit with a high gain. The high gain unit was designed to maximize the system for recording a -1 acceleration signal with a very high resolution. The low gain unit was set to the proper levele for recording the expected pesk values of the initial signale; typical recording levels were $\pm 5 \mathrm{~g}$ to $\pm 20 \mathrm{~g}$. Figure 6 is a block diagram of the electronice contained in each canister and the recording trailer.

\section{Downhole conluter}

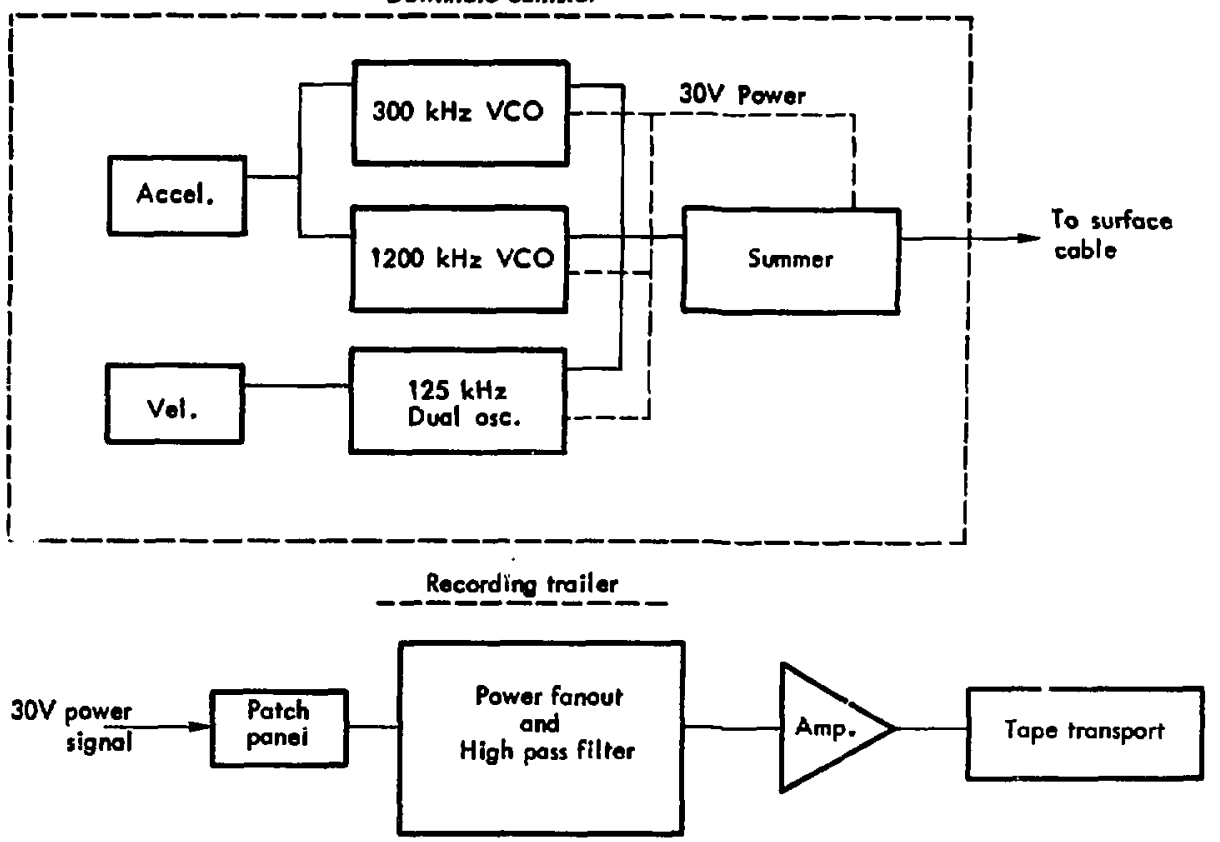

Fig. 6. Electronics block diagram for canister and recording trailer. 


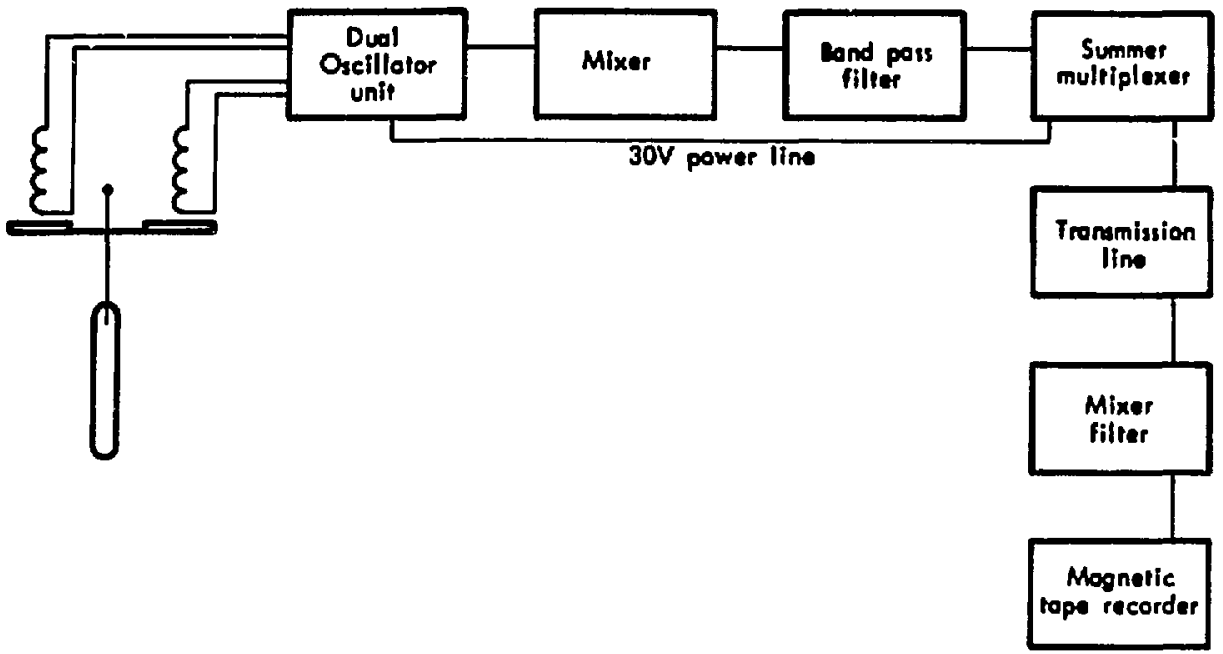

Fig. 7. Velocity gage elecironics schematic.

Instiumentation box

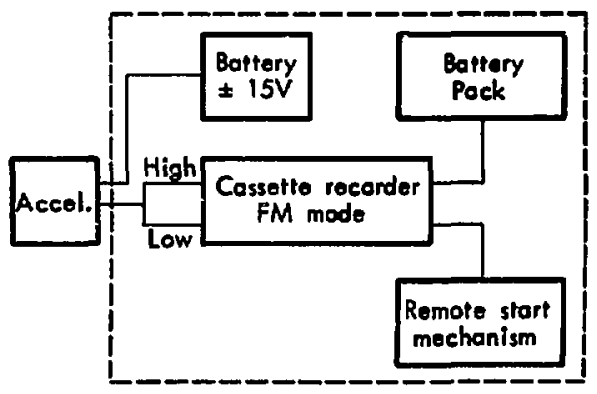

Fig. 8. Remote station recording schematic.

The dual oscillator-modulator system in the velocity gage operated with a center carrier at a nominal frequency of $125 \mathrm{kHz}$. The gain of this system was fixed by the characteristics of the particular velocity gage feeding the oscillator system, i. e., the oil viscosity. The two VCO outputs and the dual oscillator output were combined into a single signal through a "summer multiplexer" for transmission to the recording traller. A block diagram of the velocity gage elecironics is shown in Fig. 7. The RG-213U cuaxial cable transmission line accommodated the multiplexed signal carriers as well as the d.c. power for the cantster electronics. At the recording trailer, the multiplexed signals were removed from the d.c. power line and the signals were then reccrcici directly on magnetic tape.

A different recording scheme was used for the data from the rerrote stations at 12,000 and $23,000 \mathrm{ft}$. As shown in Fig. 8, the analog signals were fed directly to the FM module of a cassette tape recorder. In this module, the signals were converted to FM signals and then recorded on magnetic tape.

The analog data presented in this report were extracted f,-om the high-frequency data stored on the magnetic tape by using bandpass filters to isolate each carrier. Finally, each carrier was then demodulated 
with an IPM discriminator. Data from the remole stations on the cassette tapes were similarly retrieved except that bandpass tilters were not cequired.

\section{INSTRUMENT LMPLACEMENT}

The spall measurements instrumentaton was inutalled Juring the period of 10 January 1973 to 10 Pocuruary 1973. Before their shipment to the Rio Blanco sitc, each canister was subjocted to a series of tests to certify its performance. Firs:, each "gage modulc" was tested atatically $(-1$ g, 0, anci +1 g) to verify gage response. Then if was tesi nd on the liyge machine to test dynamic response

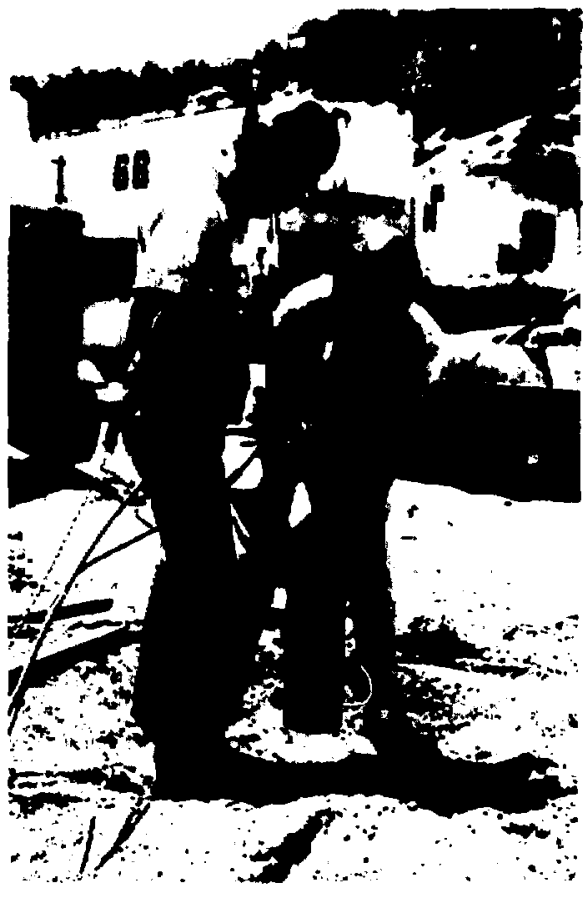

Fig. 9. Canister being placed by hand. of the gage and electronic circult. Finally. each gage module was hydrostatically teated to 1000 pal for a $30-m i n$ period as a proof test of its watertight integrity. Before beinc lowered In the appropriate instrument hole at the experiment slte, each canister was subjected to a final checkout. An emplacement otring containing the proper number of canistere tied together by 5/16-in. -diam wira rope was lowered Into each instrument hole using a drill rig. The lowering operation was systematlc. First, a aingle canistor with a $30 \mathrm{ft}$ section of wire rope was lowered and tled off at the top of the hole. Another 30-1t sectlon of wire rope (pendant) was then added and the lowering continued. When enough pendante had been added to give the proper apacing, the next canister was attached, and so corth. Perlodically during this downhole operation, all systems were checked for electronic performance and spattal consistency in emplacement lengths. Single canister which were placed at shallow depths were lowered into position by hand. Figure 9 is a photograph of a canister being lowered into position by two technicians.

The cliper, a continuous RG-81/U cable, was added to the emplacement string during this downhole operation. As with the canisters, the cliper system was tested before field installation. For the systemb test at $\mathrm{LLL}$, a length of cable was cemented into two sections of pipe butted together so that the cable was the only continuous structural member from end to end. The pipes were then pulled apart. The cliper performed as designed and experimentally confirmed that a minimum separation of 4.5 in. 
between the pipes was required to break the cable.

After the emplacement was completed and the aystems were determined to be operatlunal, the inatruments were cemented in place. The top of the cement was eatabliahed at a fairly large depth below the surface of the ground in three of the holes. This length of open hole was used to isolate the instrument cables from the near surface formation so they would not be damaged at an early time by apalling of these near-surface layers. Location of the top of the cement tis each instrument hole 18 included in Table 1.

After several days of curing for the cement, the cable cutting devices were acturted and the caniaters were released from their cable Bupports. Several of these cutters did not function properly, and at the time of the detonation a number of canisters were still partially connected by at least one end to the downhole string. A listing of the released and unreleased canisters is given in Table 1 . Only in hole, RBS-01, however, was there a link tying two adjacent canisters together.

\section{SYST EM PERFORMANCE}

With two exceptions, the originally installed instruments were functioning properly at the time of the detonation. One exception was a fallure of the signal cable attached to the canister installed at $60 \mathrm{ft}$ in hole RBS-04; it had become shorted soon after the cementirg was completed. Since it was impractical to retrieve this unit, another was placed at a depth of $35 \mathrm{ft}$ in a nearby well. This unit, identified as $04 \mathrm{Ac} 30$, was functioning properly at detonaiion time. The second exception wea intermittent operation of canleter U2Ac450 in hole RBS-02; it had also developed problems after the grouting wa completed. Apparently, a voltage regulator in the downhole electronics had falled. When the aupply voltage was increased, the poor performance of this regulator could be overridden and the unit appeared to be usable. This was rot a perfect correction, however. since the amplitudes of the carriers were appreciably decroased and they were also silghtly ahlfted in frequency. Data were obtalned from the 20 accelerometers and 16 velocity gages installed to measure spall depth; however, all records were terminated after a tlme allghtly longer than 1 Bec. This termination of data was a result of a fallure in the recording traller when a nower control circult relay was mechanlcally tripped by the larger than expected -ccelerations experienced by the traller. The peak incldent acceleration was $2.5 \mathbf{g}^{\prime} \mathrm{g}$ and the slapdown acceleration was $3.7 \mathrm{~g}^{\prime} \mathrm{s}$. The relay tripped Iminediately after slapdown occurred. A photograph of the recording traller and its shock mounting is shown as Fig. 10.

The time perlod over which dynamic motions were recorded, however, were generally longer than required to measure the peak incident acceleration to record free fall signals (spall) if any occurred. and to record the peak acceleration due to spall closure ("slapdown"). Only at the 7200-ft station where power fallure occurs at about the same time as spall clooure is there some loss of data. Therefore, the loss of power and the subsequent loss of data beyond $1 \mathrm{sec}$ did not compromise the major objective of this measurements program. 


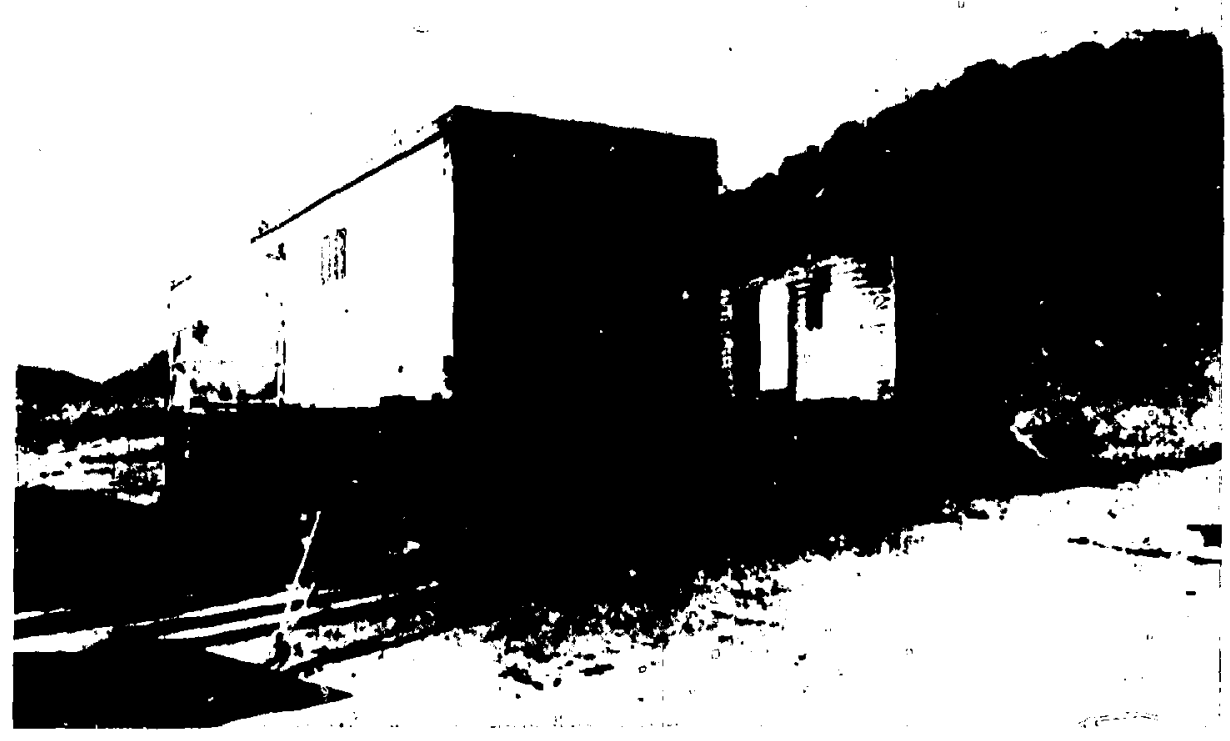

Fig. 10. Recording traller and shock mounting.

\section{Recorded Data}

All the data recorded in this measurements program are included in Figs. 11 to 29. All data, both measured and derived, pertaining to a speciflc instrument package and location are grouped under a single major figure number. The computer printouts identify each acceleration plot with elther a "HI" or "LO" which means "high range" or "low range." Peak accelerations may be read directly from the high-range plots. The low-range plots provide more detail in the $-1 \mathrm{~g}$ range, and should not be used for determining peak accelerations.

The boundaries of good data in thes: plots are delineated by the horizontal lines at the top and bottom of the plot; data beyond these lines are not ranged properly.
The analog data obtained from the accelerometers and velocity gages, except for the accelerometers at 12,000 and $23,000 \mathrm{ft}$, were digitized so that additional operations could be performed effortlessly by a computer. A first integration of the accelerometer plot provides a velocity plot which can then be compared to the original data from the velocity gages. Displacement as a function of time can be obtained independently from two different sources: (1) a second integration of the accelerometer data; and (2) a first integraiton of the velocity data. A comparison of derived and actual velocity data as well as a comparison between the two independently derived displacement plots show rather remarkable agreement. 
Table 2, Summary of recorded data.

\begin{tabular}{|c|c|c|c|c|c|c|}
\hline $\begin{array}{c}\text { Gage } \\
\text { degignation }\end{array}$ & $\begin{array}{c}\text { Depth/stant } \\
\text { range } \\
\text { (ft) }\end{array}$ & $\begin{array}{c}\text { Time of } \\
\text { arrival } \\
\text { (me) }\end{array}$ & $\begin{array}{c}\text { Peak } \\
\text { Incident } \\
\text { acceleration } \\
\left(\mathrm{g}^{\prime} \mathrm{B}\right) \\
\end{array}$ & $\begin{array}{c}\text { Spall } \\
\text { closure } \\
\left(g^{\prime} s\right) \\
\end{array}$ & $\begin{array}{c}\text { Peak } \\
\text { incident } \\
\text { velocity } \\
\text { (fps) }\end{array}$ & $\begin{array}{c}\text { Peak } \\
\text { displacemont } \\
\text { (ft) } \\
\end{array}$ \\
\hline $00 A C 00$ & $15 / 6216$ & 542 & 3.0 & 12.5 & 3.0 & 0.25 \\
\hline $\begin{array}{l}01 \mathrm{AC} B 0 \\
01 \mathrm{AC} 150\end{array}$ & $\begin{array}{l}61 / 6170 \\
149 / 6082\end{array}$ & $\begin{array}{l}527.5 \\
516.8\end{array}$ & $\begin{array}{l}9.5 \\
7.9\end{array}$ & $\begin{array}{l}8.8 \\
8.7\end{array}$ & $\begin{array}{l}3.7 \\
2.5\end{array}$ & $\begin{array}{l}0.18 \\
0.16\end{array}$ \\
\hline $\begin{array}{l}02 A C 350 \\
02 A C 450 \\
02 A C 600\end{array}$ & $\begin{array}{l}352 / 5879 \\
452 / 5779 \\
604 / 5627\end{array}$ & $\begin{array}{l}492.7 \\
482.9 \\
470.4\end{array}$ & $\begin{array}{r}8.8 \\
10.0 \\
8.5\end{array}$ & $=$ & $\begin{array}{l}2.2 \\
2.0 \\
1.6\end{array}$ & $\begin{array}{l}0.10 \\
0.12 \\
0.092\end{array}$ \\
\hline $\begin{array}{l}03 A C 720 \\
03 A C 820\end{array}$ & $\begin{array}{l}723 / 5508 \\
821 / 5410\end{array}$ & $\begin{array}{l}459.7 \\
448.5\end{array}$ & $\begin{array}{l}11.0 \\
13.0\end{array}$ & $=$ & $\begin{array}{l}2.2 \\
3.25\end{array}$ & $\begin{array}{l}0.09 \\
0.09\end{array}$ \\
\hline $\begin{array}{l}04 A C 30 \\
04 A C 120\end{array}$ & $\begin{array}{l}35 / 6683 \\
120 / 6610\end{array}$ & $\begin{array}{l}570 \\
554\end{array}$ & $\begin{array}{l}3.8 \\
4.2\end{array}$ & $\begin{array}{l}4.1 \\
3.8\end{array}$ & $\begin{array}{l}1.9 \\
2.1\end{array}$ & $\begin{array}{l}0.14 \\
0.10\end{array}$ \\
\hline $\begin{array}{l}05 A C 280 \\
05 A C 380\end{array}$ & $\begin{array}{l}285 / 6449 \\
398 / 6344\end{array}$ & $\begin{array}{l}537 \\
526\end{array}$ & $\begin{array}{l}4.0 \\
3.3\end{array}$ & 5.5 & $\begin{array}{l}1.4 \\
1.3\end{array}$ & $\begin{array}{l}0.08 \\
0.07\end{array}$ \\
\hline $\begin{array}{l}7300 A C 00 \\
06 A C 90 \\
06 A C 190 \\
06 A C 290 \\
06 A C 550 \\
06 A C 630\end{array}$ & $\begin{array}{l}15 / 9516 \\
107 / 9560 \\
190 / 9506 \\
288 / 9443 \\
532 / 9288 \\
630 / 9227\end{array}$ & $\begin{array}{l}806 \\
778 \\
767 \\
760 \\
741 \\
732\end{array}$ & $\begin{array}{l}2.0 \\
1.8 \\
1.4 \\
1.35 \\
1.9 \\
2.2\end{array}$ & $\begin{array}{c}\text { Data lost } \\
>7 \\
1.2 \\
= \\
=\end{array}$ & $\begin{array}{l}2.2 \\
1.4 \\
1.2 \\
0.9 \\
0.8 \\
0.9\end{array}$ & $\begin{array}{l}0.14 \\
0.08 \\
0.06 \\
0.05 \\
0.03 \\
0.036\end{array}$ \\
\hline $\begin{array}{l}12000 A C 00 \\
23000 A C 00\end{array}$ & $\begin{array}{l}15 / 13450 \\
15 / 23828\end{array}$ & $\begin{array}{l}\text { Unknown } \\
\text { Unknown }\end{array}$ & $\begin{array}{l}1.8 \\
0.6\end{array}$ & $>4.0$ & $\begin{array}{l}\text { Unknown } \\
\text { Unknown }\end{array}$ & $\begin{array}{l}\text { Unknown } \\
\text { Untenown }\end{array}$ \\
\hline
\end{tabular}

Typically, the acceleration data are superior to the velocity data. The reason is that the low-amplitude signals genel-ated by the Rio Blanco detonation were generally below the operating range of the velocity gages. Since these were the only gages available, they were used and operated at their lowest range. As a result, the signal-to-noise ratio for these signals is very poor as seen in the velocity data prior to the arrival of the firsi pulse. Some of this noise can still be eliminated to signific sntly improve the quality of the velocity data. This would also bring the derived values into even closer agreement.

Table 2 provides a summary of the key information contained in Figs. 11 to 29.
Included data are the time of arrival of the first pulse (TOA), the incident peak acceleration, the peak velocity, the peak displacement, and the peak acceleration due to spall closure where it existsi. The velocity and displacement values are derived from the acceleration data.

No information is presented on the cliper systems because no spall separation was large enough to break a cable, i. e., all the cables are still continuous over their entire length. Again since evidence based on laboratory tests indicate a separation of $4.5 \mathrm{in}$. is required to break the cliper cable, either there were no spall separations or the spall separations must be less than 4.5 in. Supporting 

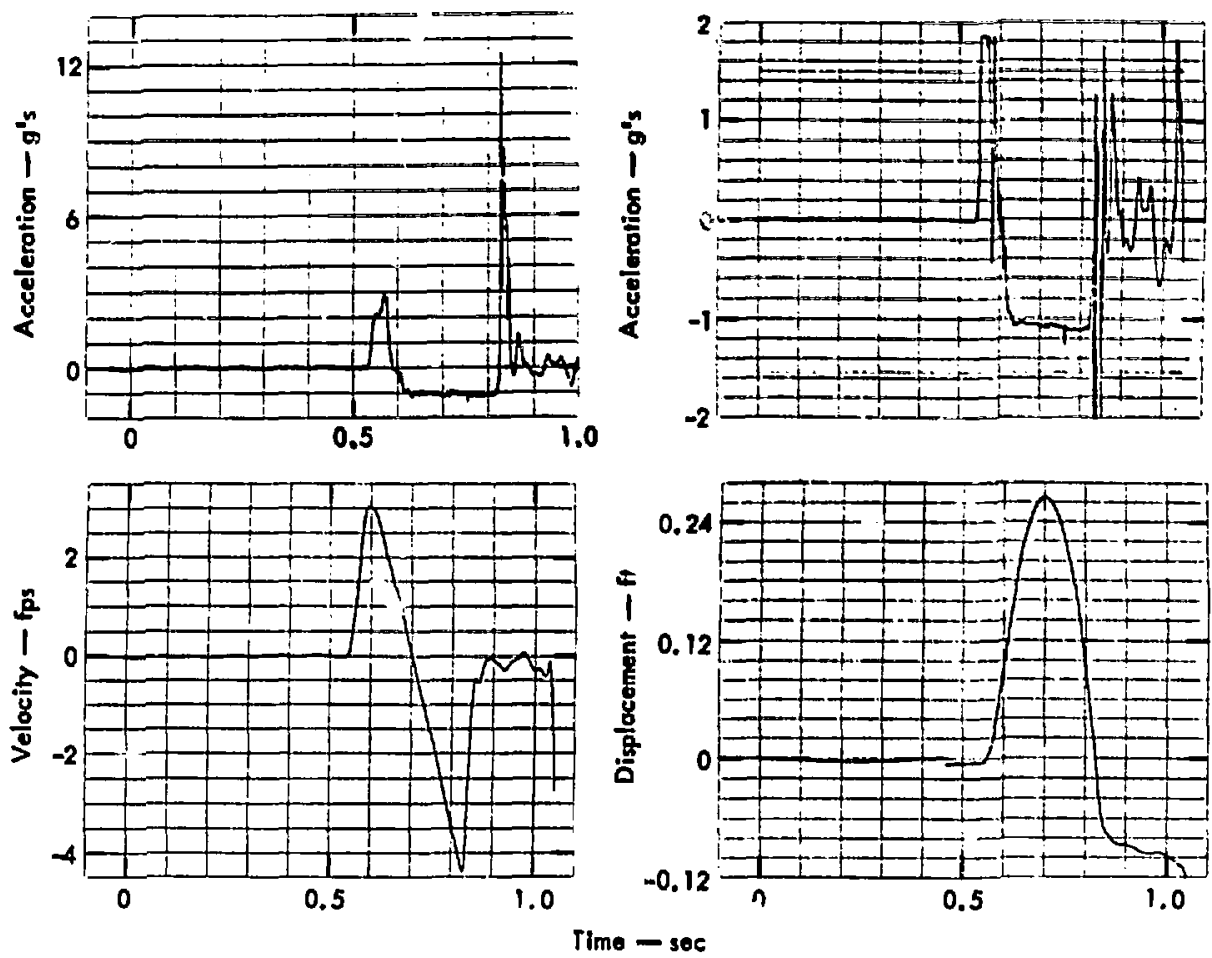

Fig. 11. Data from surface zero station.

evidence can be gotter from Table 2 and Fig. 9d by observing that the maximum temporary displacement at the EW was only 0.25 ft or 3 in.: again, this is not enuugh to break a cliper cable. 


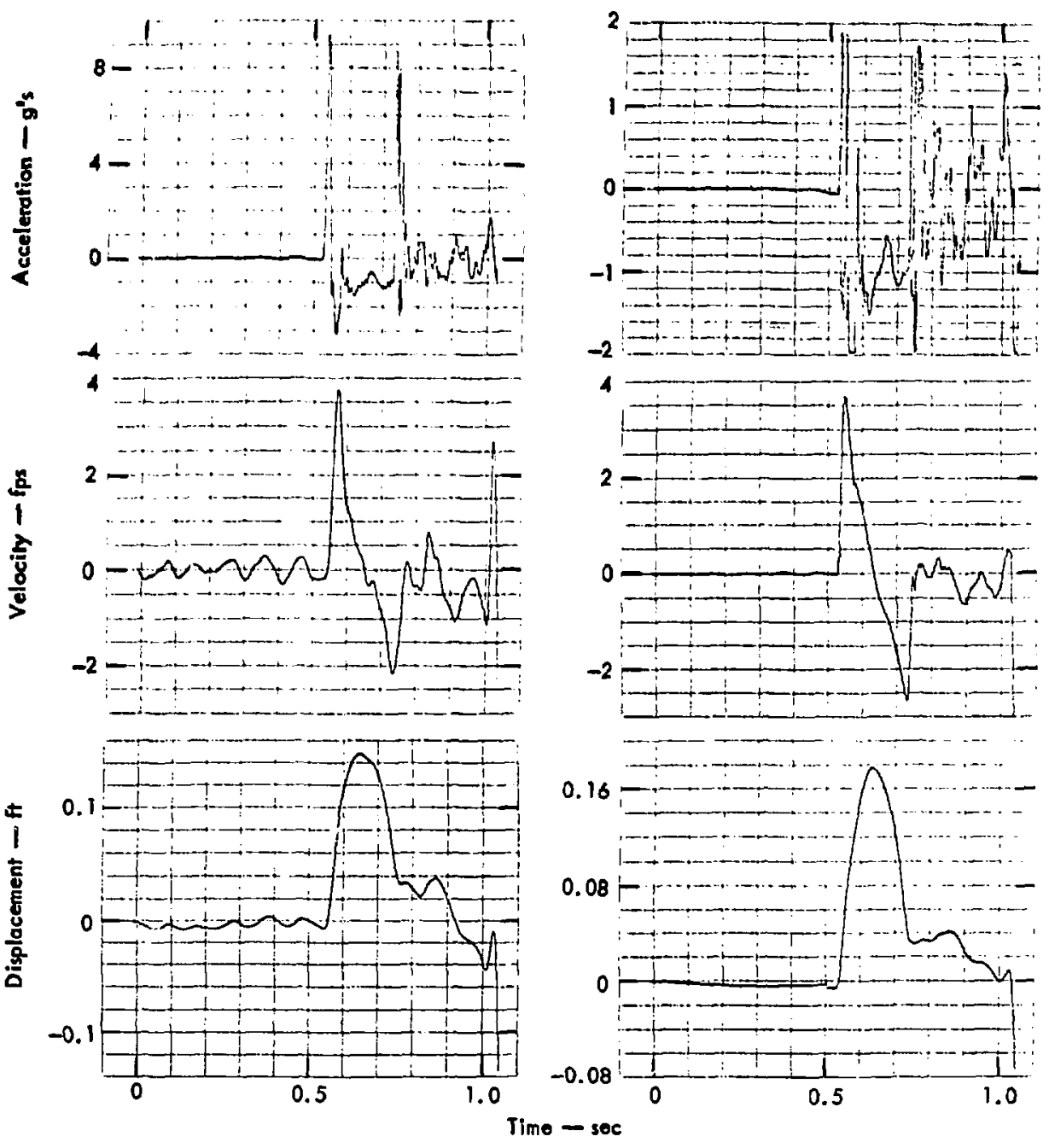

Fig. 12. Data from 61-ft depth in RBS-01 instrument hole. 

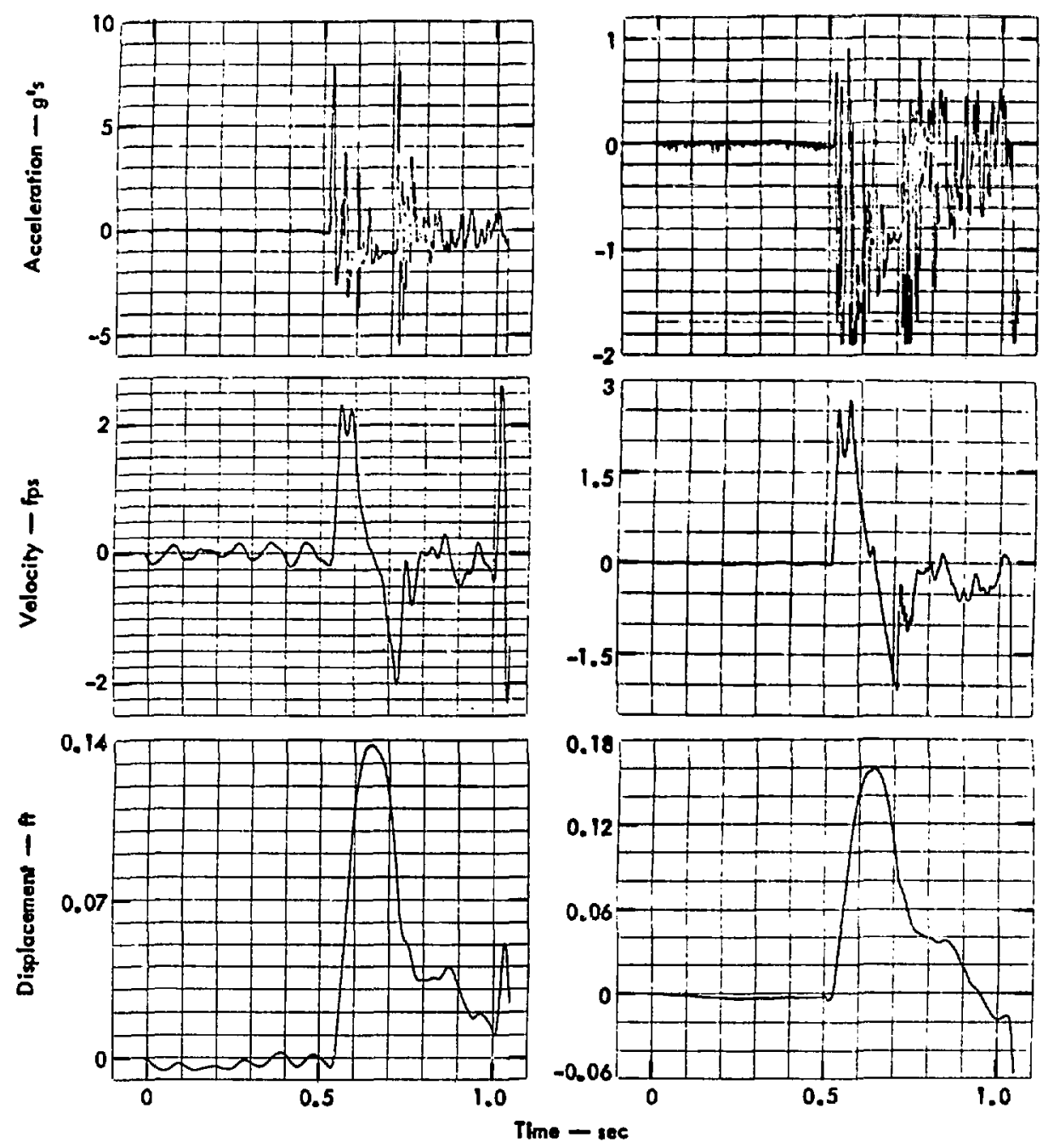

Fig. 13. Data from 149-ft depth in RBS-01 instrument hole. 

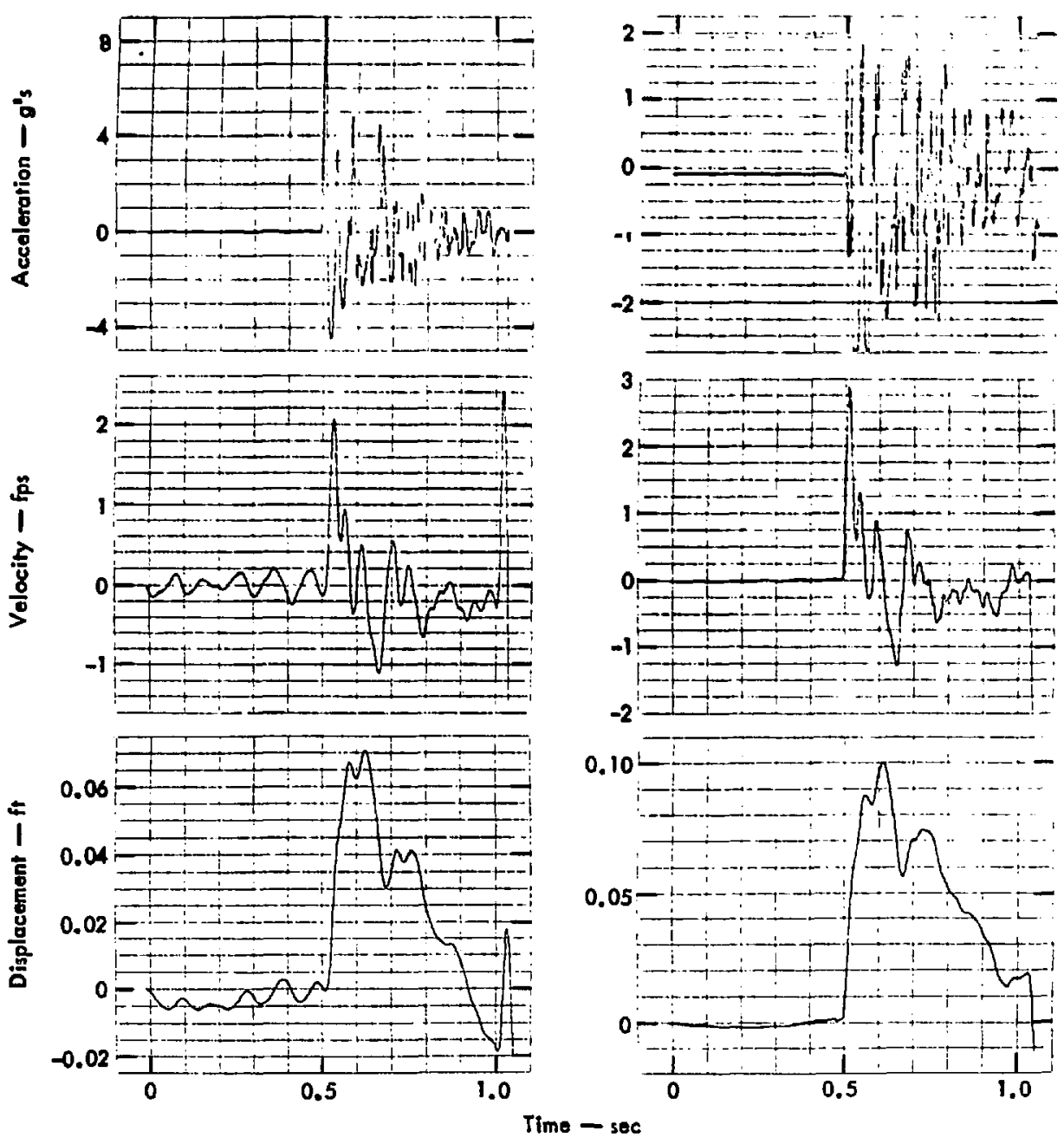

Fig. 14. Data from 352-ft depth in RBS-02 instrument hole. 

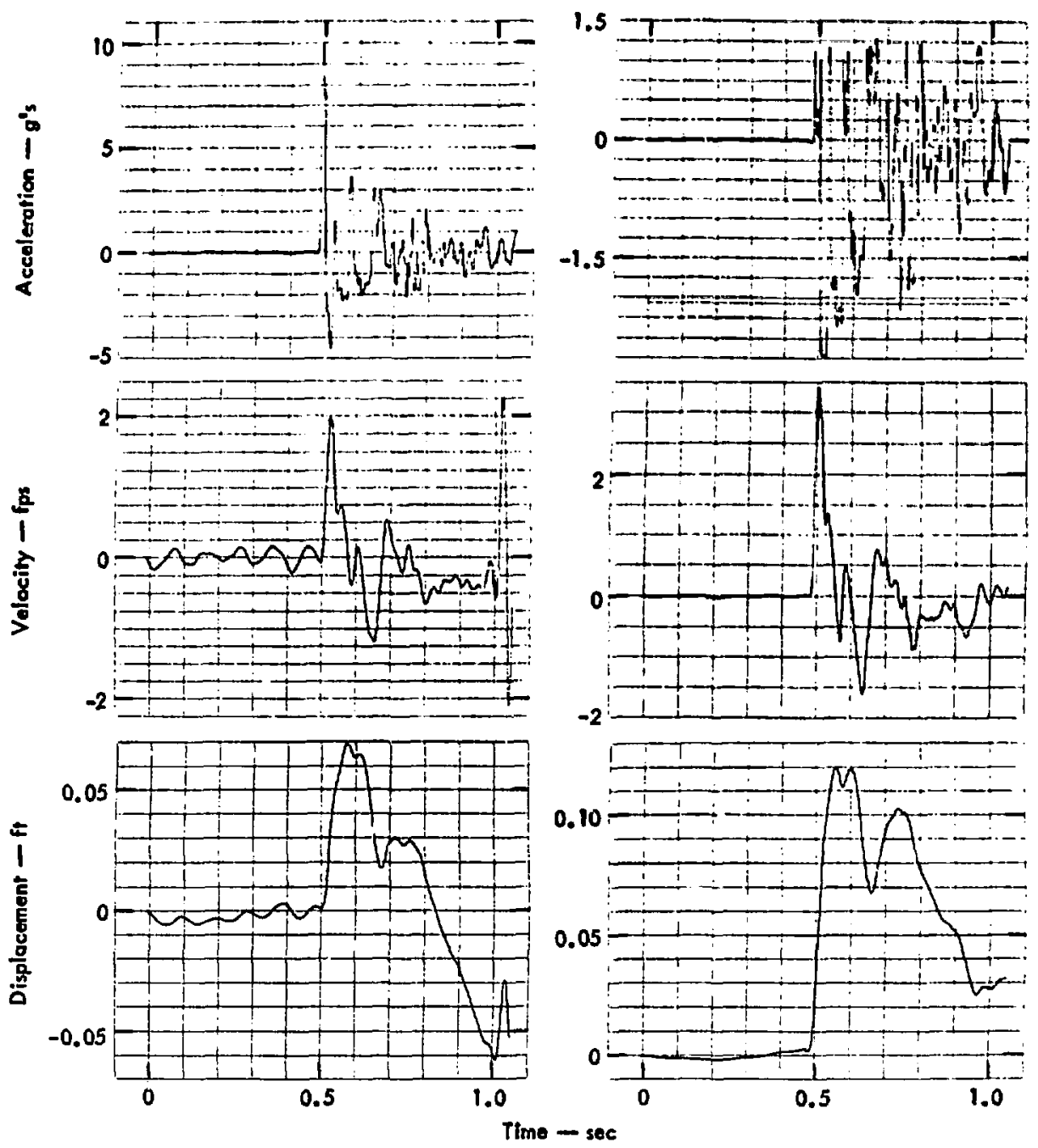

Fig. 15. Data from 452-depth in RBS-02 instrument hole. 


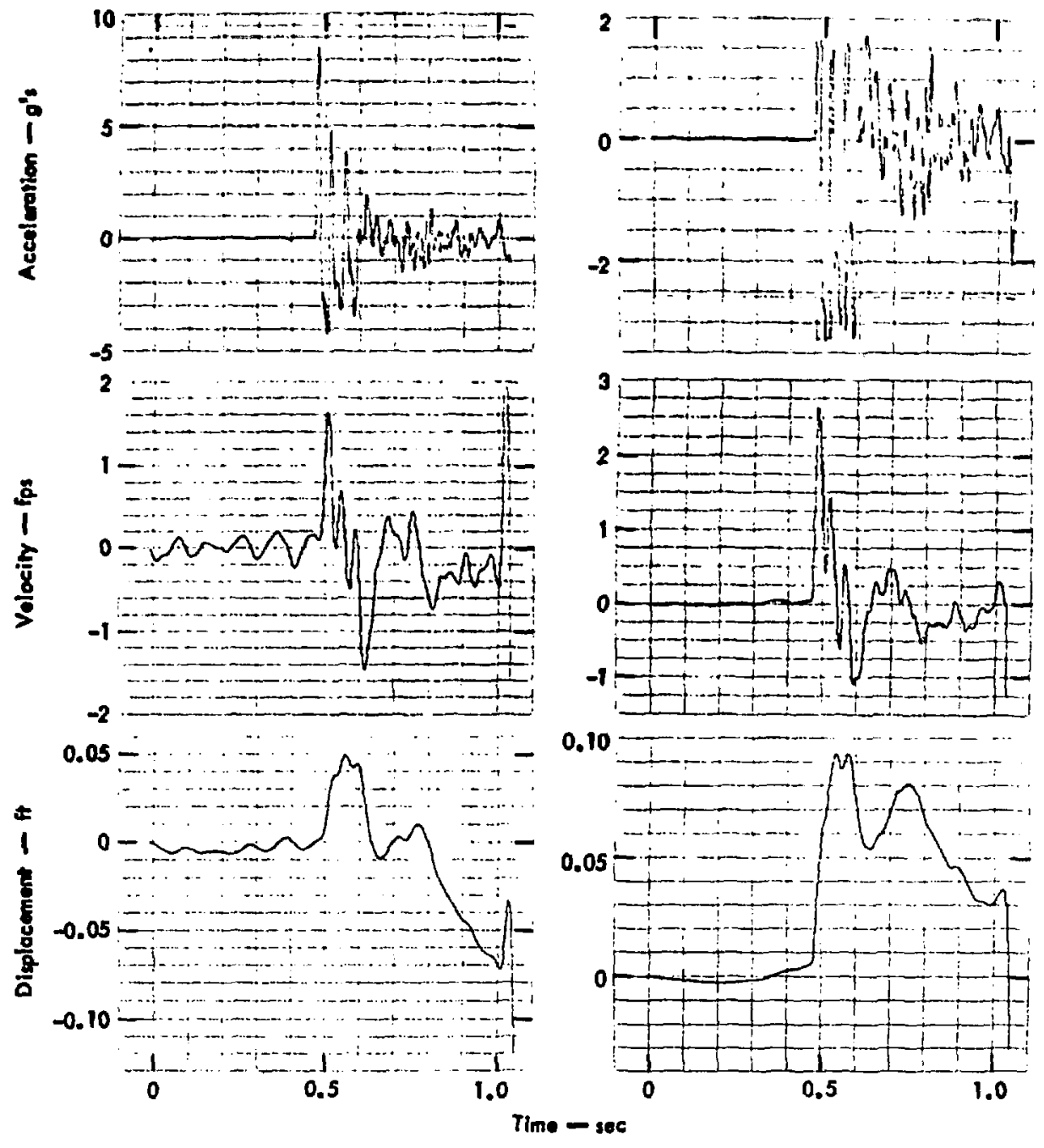

Fig. 16. Data from 604-ft depth in RBS-02 instrument hole. 

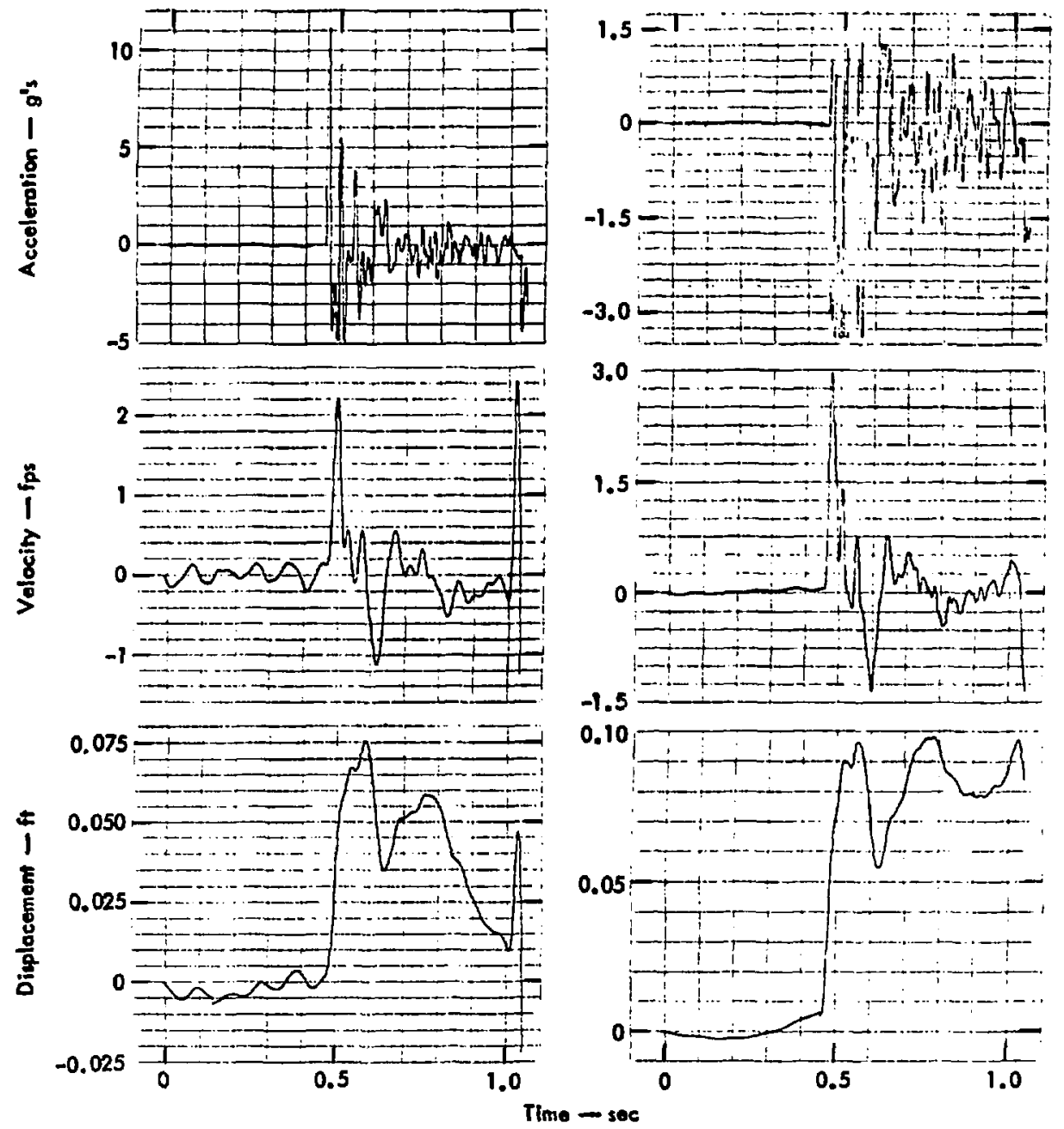

Fig. 17. Data from 723-ft depth in RBS-03 instrument hole. 

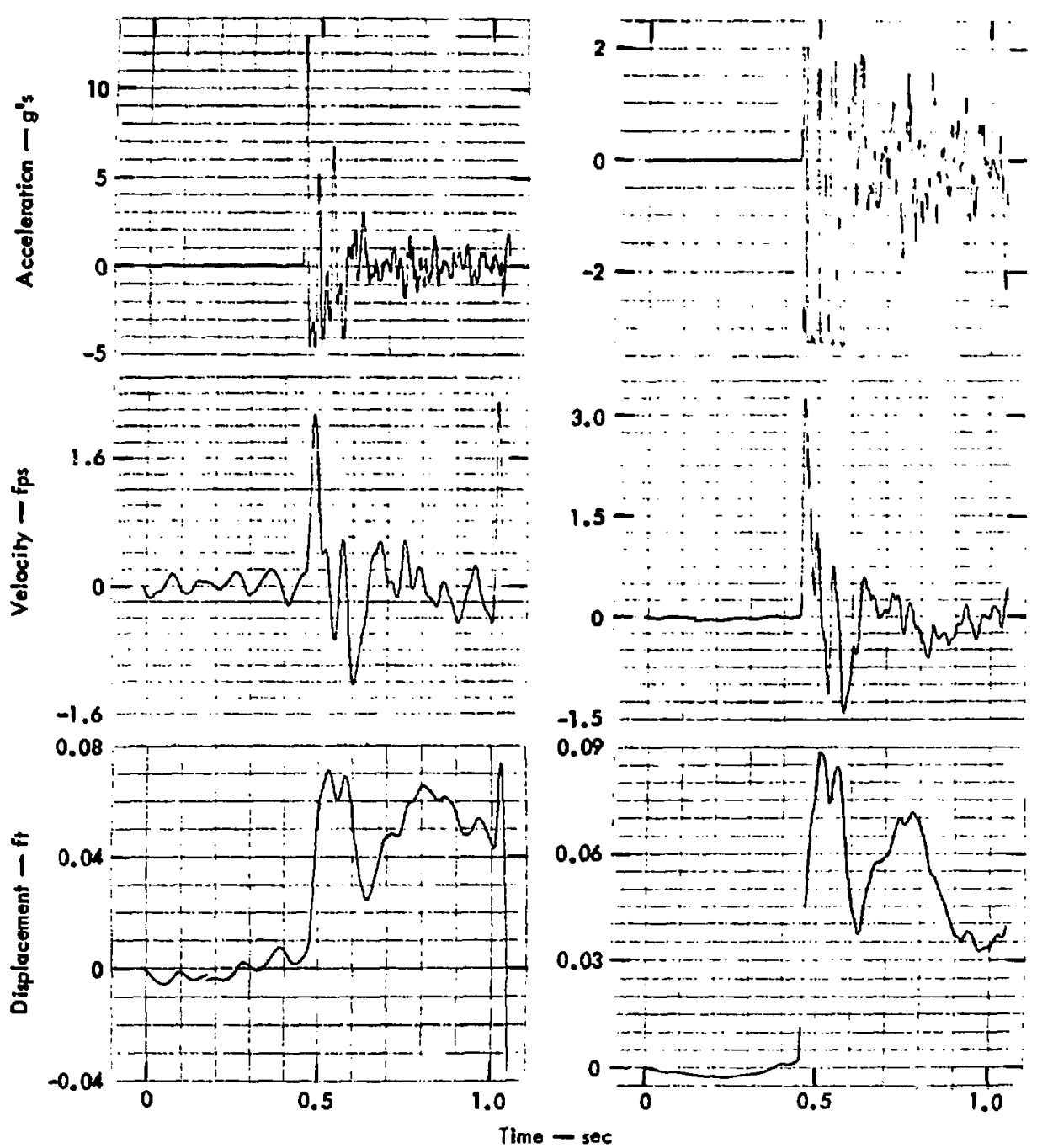

Fig. 18. Data from 821-ft depth in RBS-03 instrument hole. 


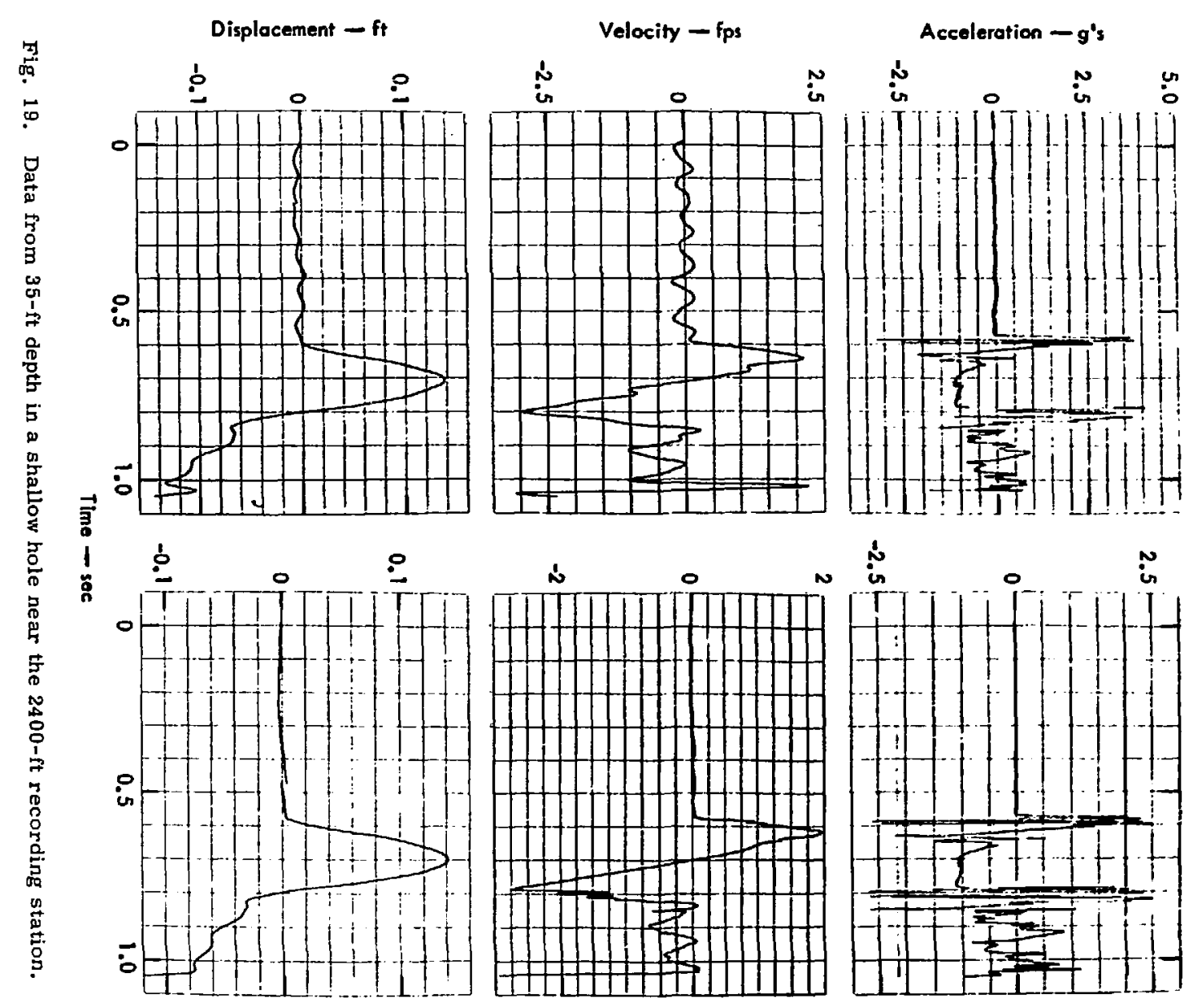



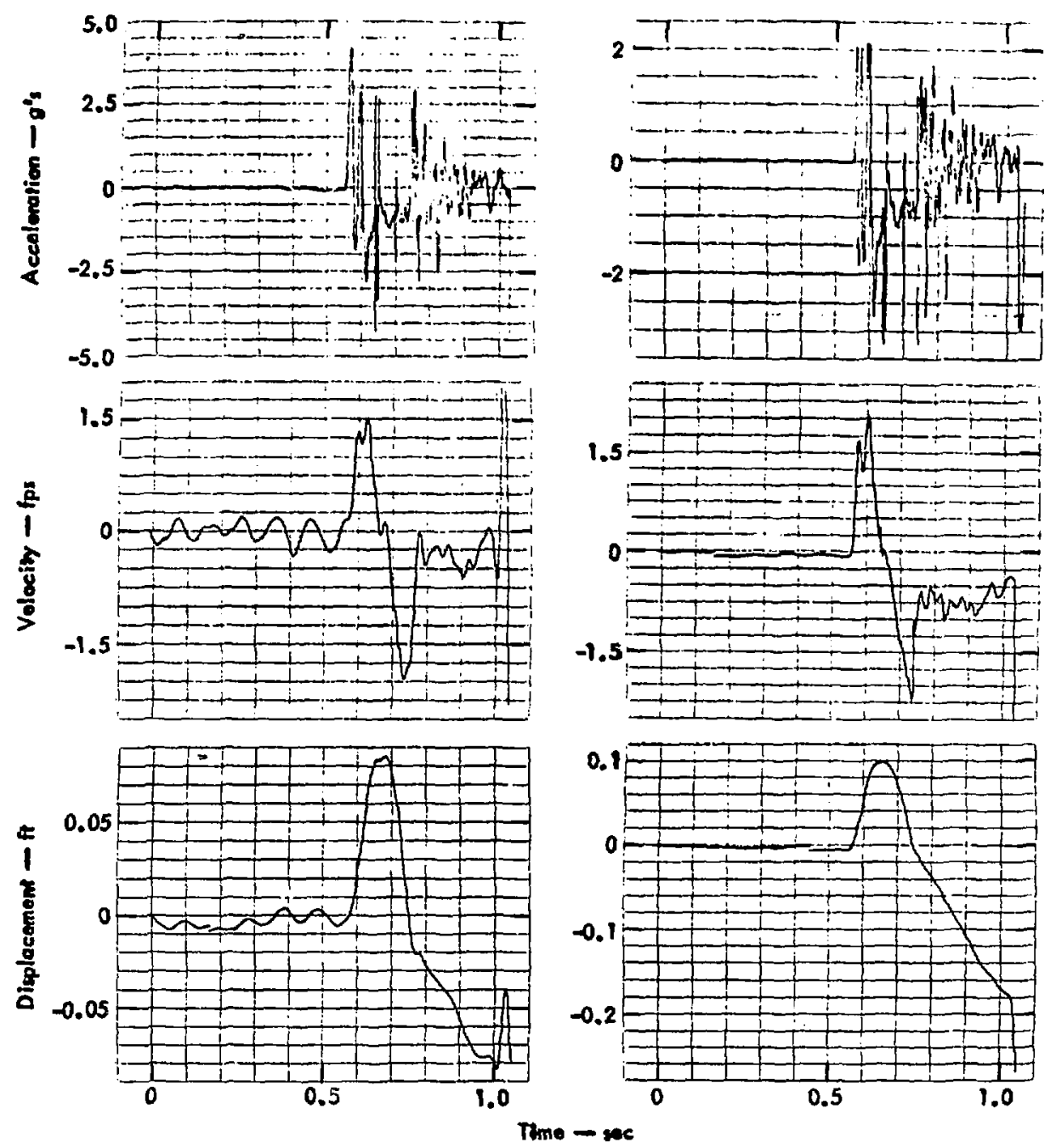

Fig. 20. Data from 120-ft depth in RBS-04 instrument hole. 


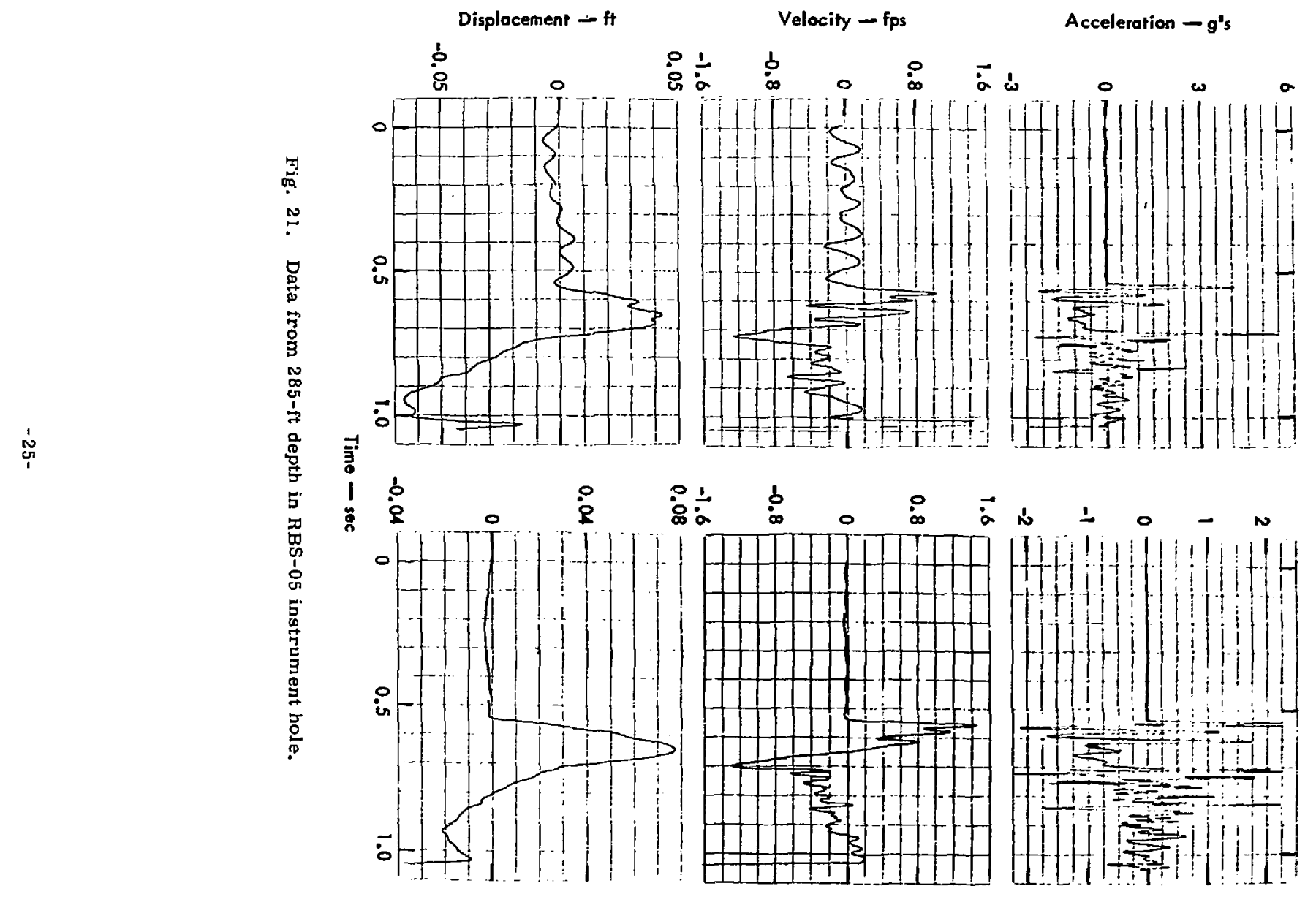




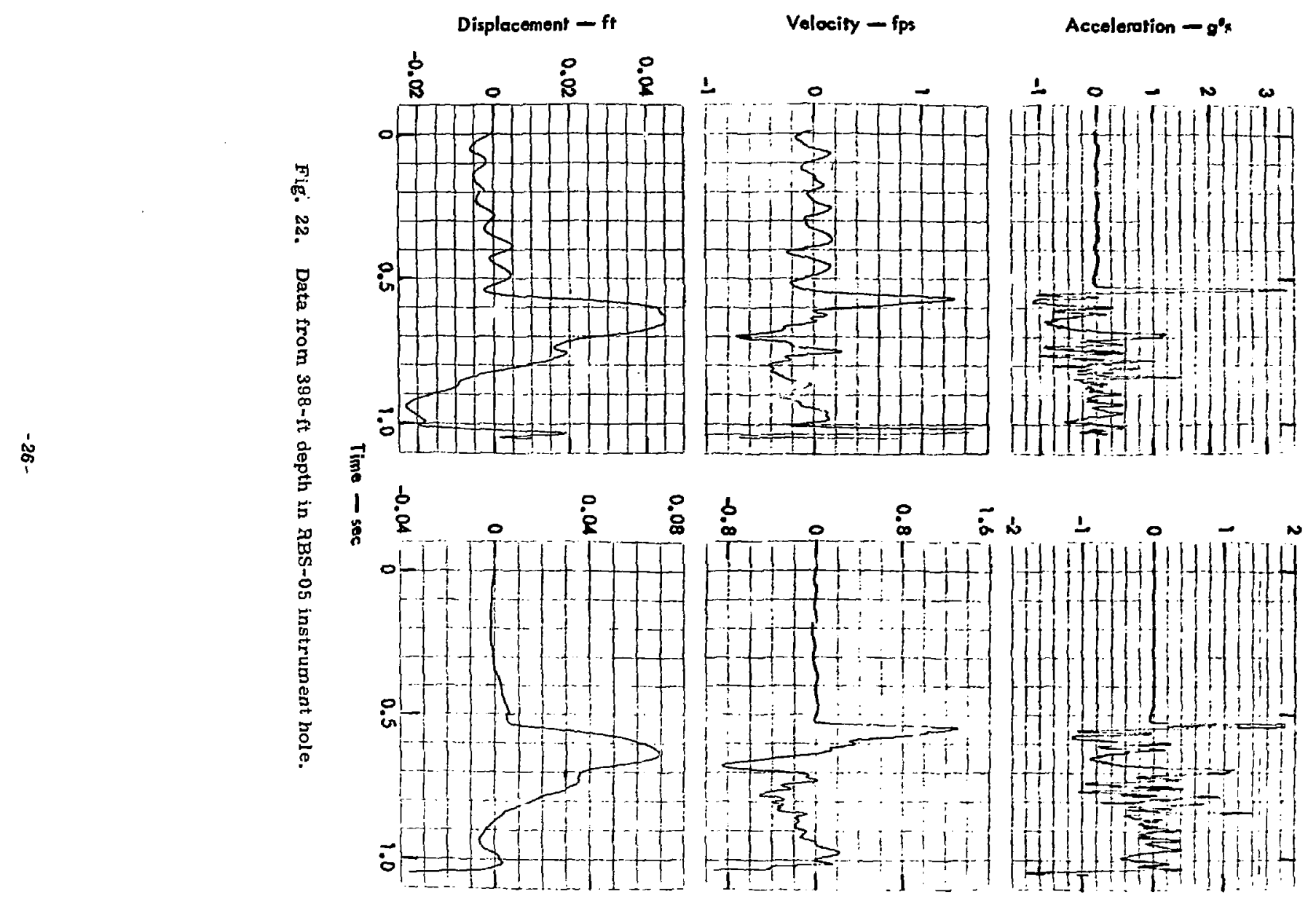




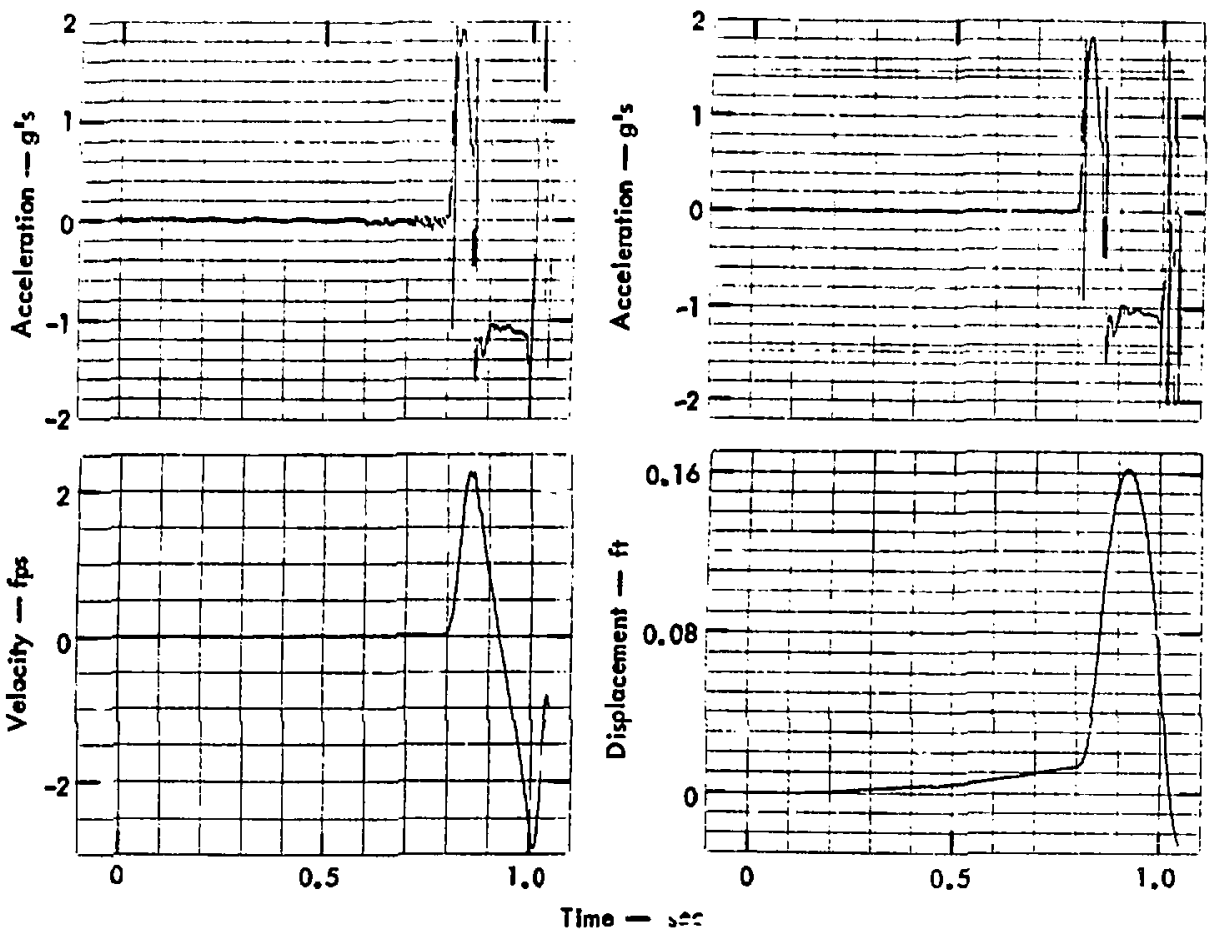

Rig. 23. Data from the 7200-ft surface station. 


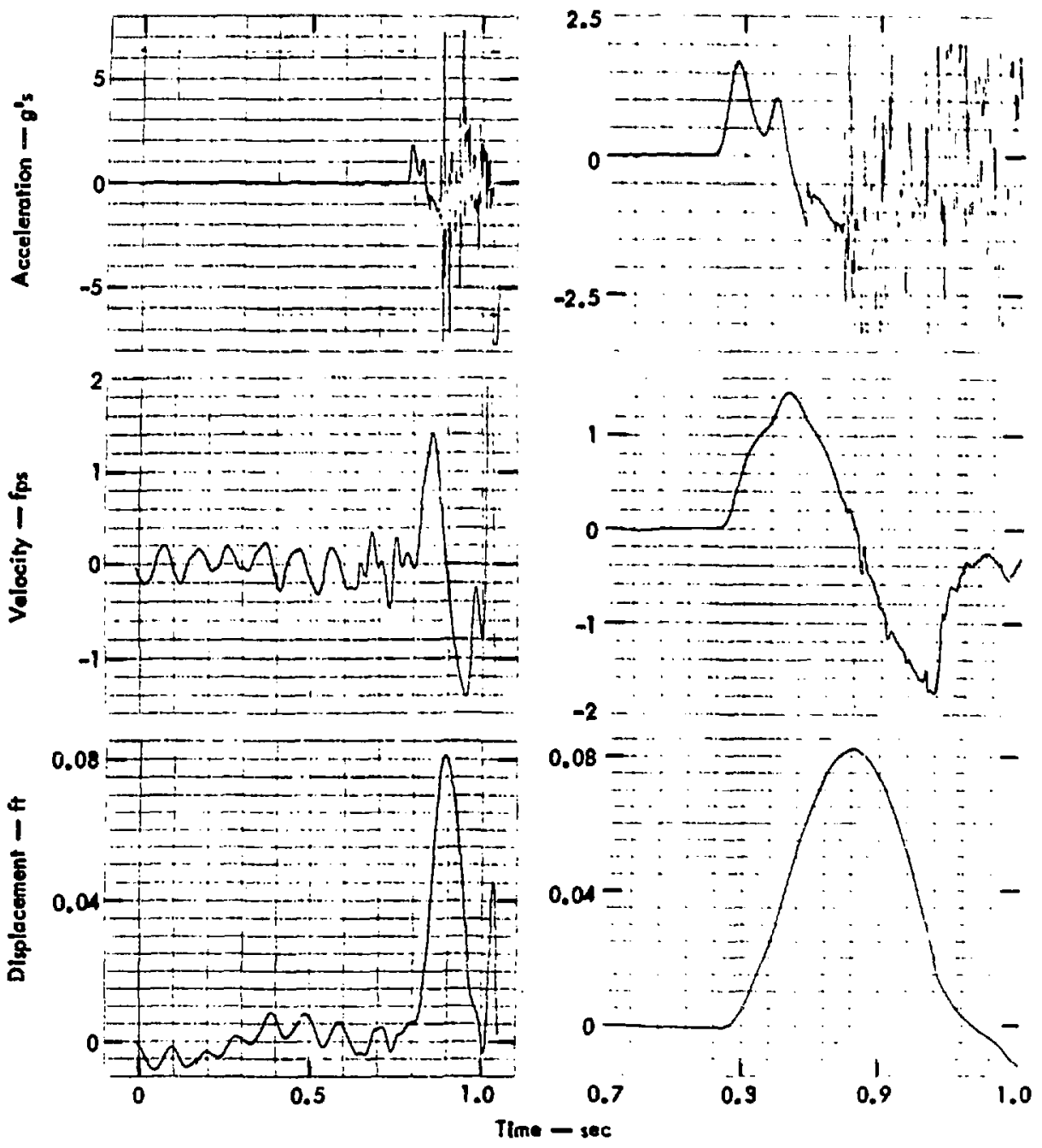

Fig. 24. Data from 107-ft depth in RBS-06 instrument hole. 


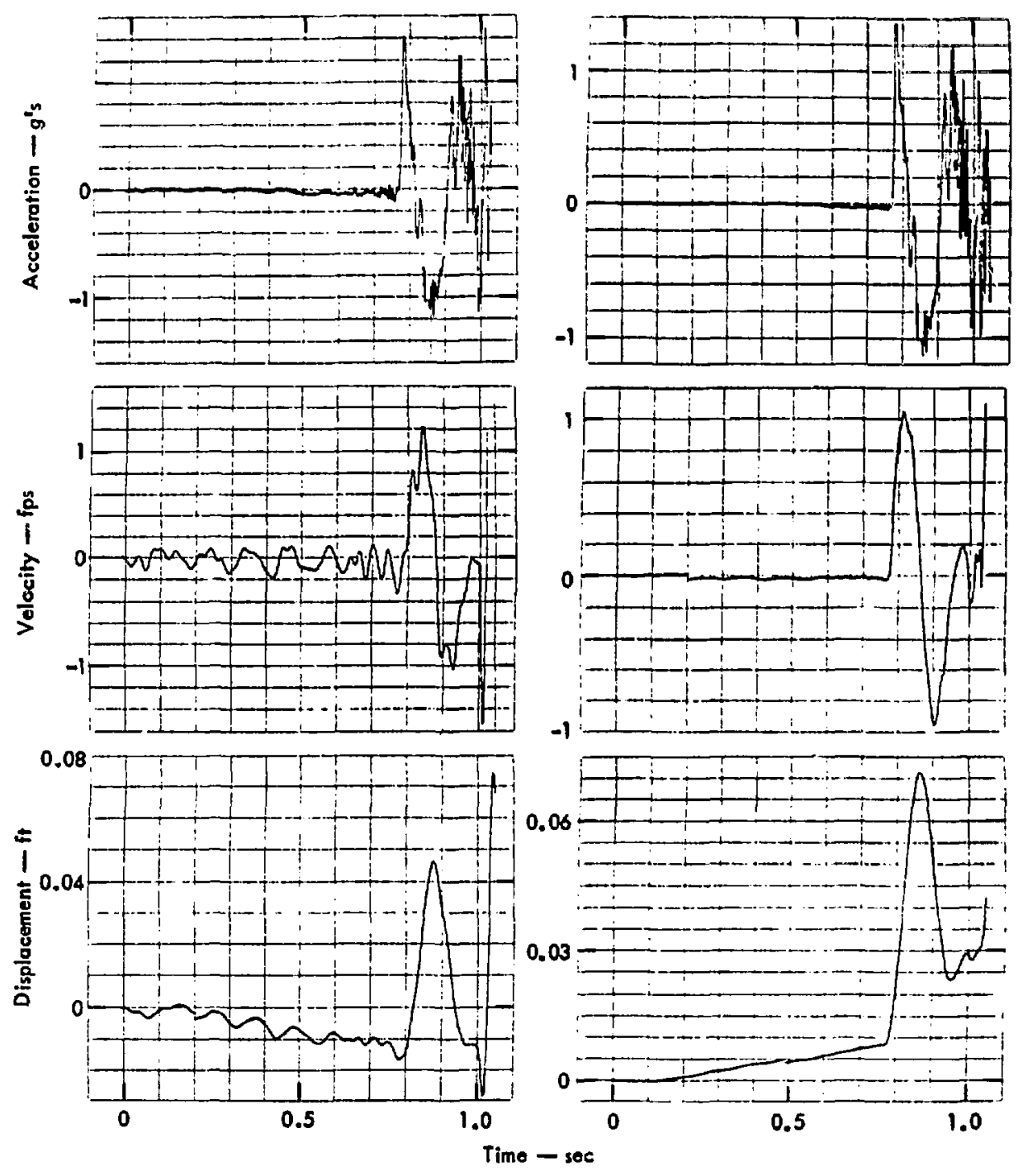

Fig. 25. Data from 190-ft depth in RBS-06 instrumen hole. 

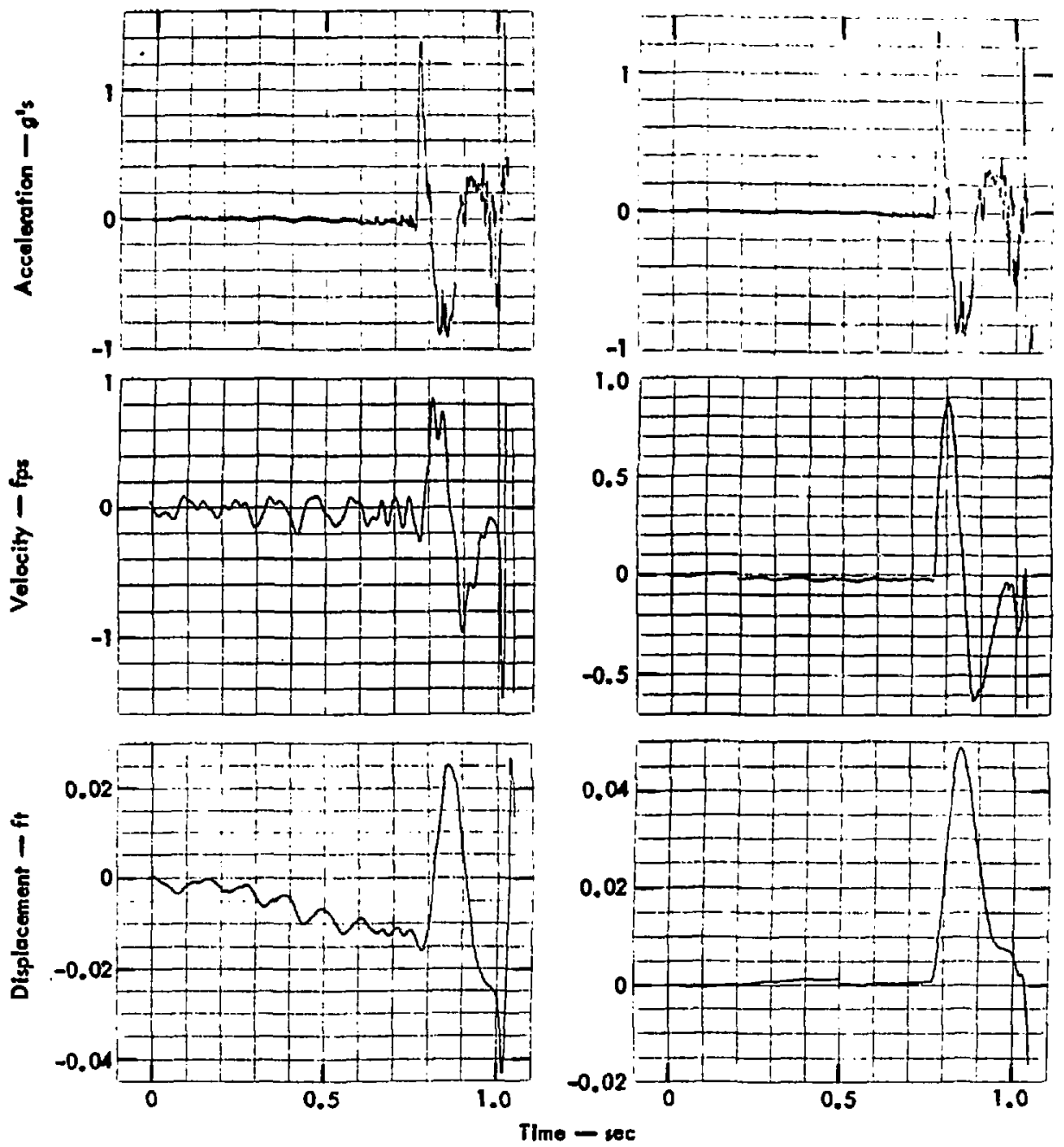

Fig. 26. Data from 288-ft depth in RBS-06 instrument hole. 


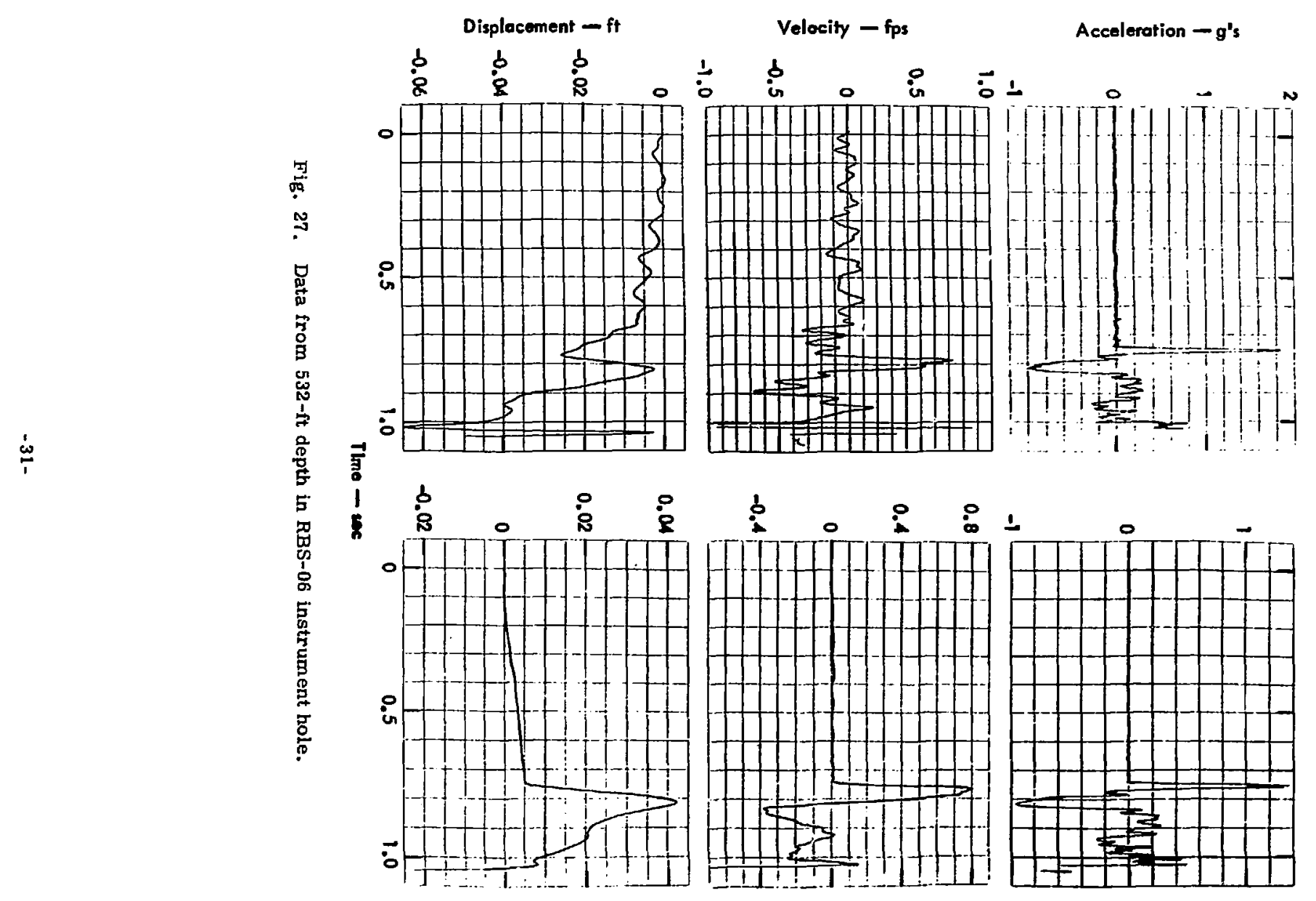




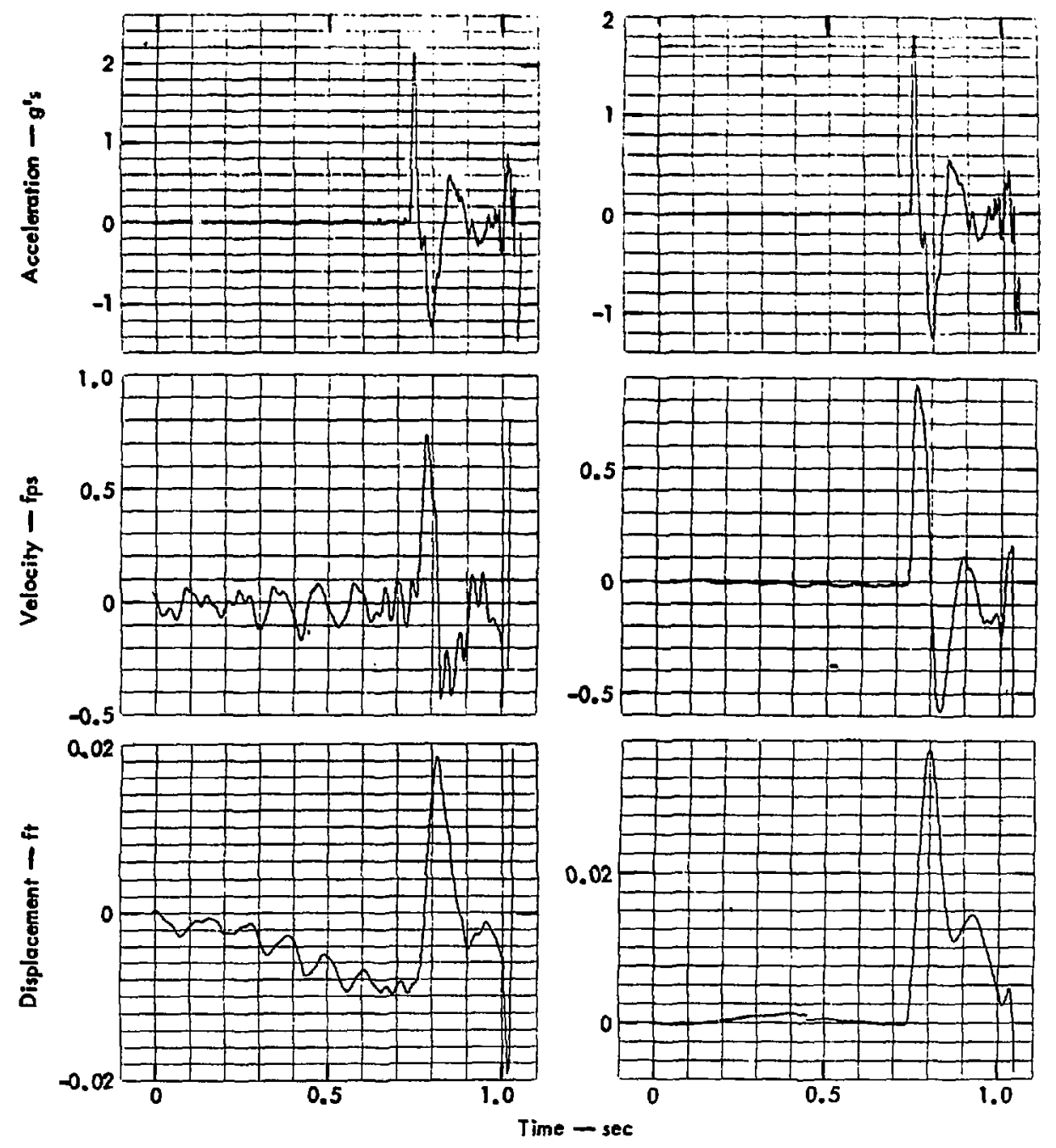

Fig. 28. Data from 630-ft depth in RBS-06 instrument hole. 


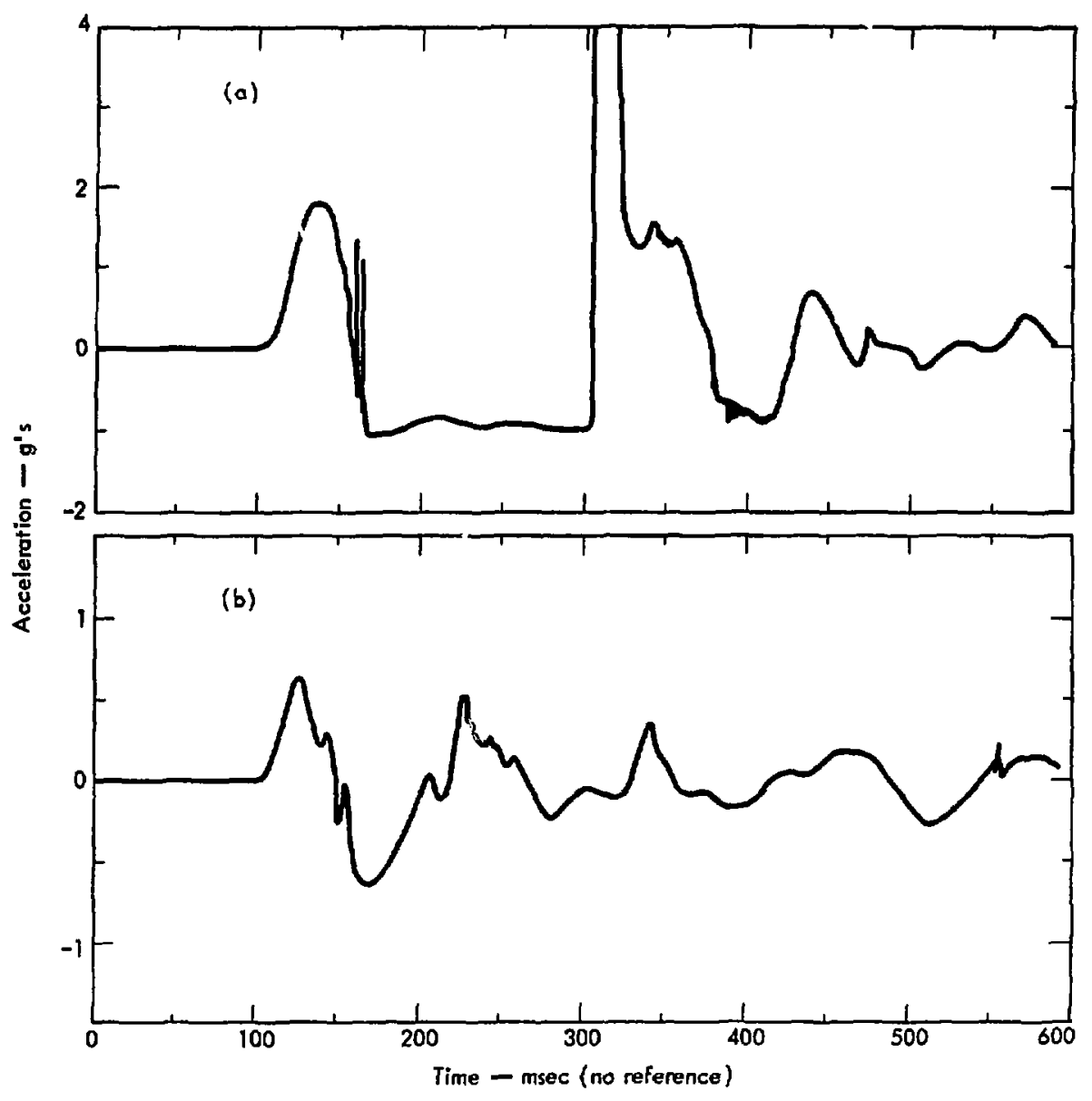

Fig. 29. Data from (a) the 12,000-ft station, and (b) the 23,000-ft station. 


\section{Conclusions}

The instrumentation, recording systems and data retrieval methods used for the spall measurements program in Project
Rio Blanco have provided the basic information needed to analyze the depth and extent of spall within reasonable limits.

\section{Acknowledgments}

There is no way to adequately describe the total effort required to obtain the data presented in this report ur to single out each of the many people who were involved. However, the success of this measurement program was due largely to the work of Thomas Barlow, Project Mechanical
Engineer. Sam Spataro, Project Electronics Engineer; and Norman Stewart, the senior technician in charge of the assembly and emplacement of canisters. Our thanks and appreciation are extended to all of the active participants in the spall measurements program for its successful completion. 